BNL-94308-2010-IR

\title{
Self-degradable Cementitious Sealing Materials
}

\author{
Toshifumi Sugama and Thomas Butcher
}

October 2010

\author{
Sustainable Energy Technologies Department \\ Brookhaven National Laboratory
}

\section{U.S. Department of Energy \\ [DOE Energy Efficiency and Renewable Energy], [DOE Geothermal Technologies Program]}

Notice: This manuscript has been authored by employees of Brookhaven Science Associates, LLC under Contract No. DE-AC02-98CH10886 with the U.S. Department of Energy. The publisher by accepting the manuscript for publication acknowledges that the United States Government retains a non-exclusive, paid-up, irrevocable, world-wide license to publish or reproduce the published form of this manuscript, or allow others to do so, for United States Government purposes. 


\section{DISCLAIMER}

This report was prepared as an account of work sponsored by an agency of the United States Government. Neither the United States Government nor any agency thereof, nor any of their employees, nor any of their contractors, subcontractors, or their employees, makes any warranty, express or implied, or assumes any legal liability or responsibility for the accuracy, completeness, or any third party's use or the results of such use of any information, apparatus, product, or process disclosed, or represents that its use would not infringe privately owned rights. Reference herein to any specific commercial product, process, or service by trade name, trademark, manufacturer, or otherwise, does not necessarily constitute or imply its endorsement, recommendation, or favoring by the United States Government or any agency thereof or its contractors or subcontractors. The views and opinions of authors expressed herein do not necessarily state or reflect those of the United States Government or any agency thereof. 
Self-degradable Cementitious Sealing Materials

Prepared for

The U.S. Department of Energy

Energy Efficiency and Renewable Energy

Geothermal Technologies Program

1000 Independence Avenue SW

Washington, D.C. 20585

Prepared by

Toshifumi Sugama and Thomas Butcher

Sustainable Energy Technologies Department

Brookhaven National Laboratory

Upton, NY 11973-5000

Lance Brothers

Halliburton

2600 S. $2^{\text {nd }}$ Street

P.O. Drawer 1431

Duncan, OK 73536-0442

Daniel Bour

AltaRock Energy, Inc.

7900 E. Green Lake Drive N., Suite 202

Seattle, WA 98103-4818

October 2010

Notice: This manuscript has been authored by employee of Brookhaven Science Associates, LLC under Contract No. DE-AC02-98CH 10886 with the U.S.

Department of Energy. The publisher by accepting the manuscript for publication acknowledges that the United States Government retains a non-exclusive, paid-up, irrevocable, world-wide license to publish or reproduce the published form of this manuscript, or allow others to do so, for the United States Government purposes. 


\begin{abstract}
A self-degradable alkali-activated cementitious material consisting of a sodium silicate activator, slag, Class $\mathrm{C}$ fly ash, and sodium carboxymethyl cellulose (CMC) additive was formulated as one dry mix component, and we evaluated its potential in laboratory for use as a temporary sealing material for Enhanced Geothermal System (EGS) wells. The self-degradation of alkali-activated cementitious material (AACM) occurred, when AACM heated at temperatures of $\geq 200^{\circ} \mathrm{C}$ came in contact with water. We interpreted the mechanism of this water-initiated self-degradation as resulting from the in-situ exothermic reactions between the reactants yielded from the dissolution of the nonreacted or partially reacted sodium silicate activator and the thermal degradation of the CMC. The magnitude of self-degradation depended on the CMC content; its effective content in promoting degradation was $\geq 0.7 \%$. In contrast, no self-degradation was observed from CMC-modified Class $\mathrm{G}$ well cement. For $200^{\circ} \mathrm{C}$-autoclaved AACMs without $\mathrm{CMC}$, followed by heating at temperatures up to $300^{\circ} \mathrm{C}$, they had a compressive strength ranging from 5982 to 4945 psi, which is $\sim 3.5$-fold higher than that of the commercial Class G well cement; the initial- and final- setting times of this AACM slurry at $85^{\circ} \mathrm{C}$ were $\sim 60$ and $\sim 90 \mathrm{~min}$. Two well-formed crystalline hydration phases, $1.1 \mathrm{~nm}$ tobermorite and calcium silicate hydrate (I), were responsible for developing this excellent high compressive strength. Although $\mathrm{CMC}$ is an attractive, as a degradationpromoting additive, its addition to both the AACM and the Class $\mathrm{G}$ well cement altered some properties of original cementitious materials; among those were an extending their setting times, an increasing their porosity, and lowering their compressive strength. Nevertheless, a 0.7 \% CMC-modified AACM as self-degradable cementitious material displayed the following properties before its breakdown by water; 120 min initial- and $\sim 180$ min final-setting times at $85^{\circ} \mathrm{C}$, and 1825 to 1375 psi compressive strength with 51.2 to $55.0 \%$ porosity up to $300^{\circ} \mathrm{C}$.
\end{abstract}




\section{Introduction}

A critical operation in assembling and constructing the enhanced geothermal system (EGS) is to create the hydrothermal reservoir in an impermeable rock stratum at temperatures $\geq 200^{\circ} \mathrm{C}$, located at $\sim 3-10 \mathrm{~km}$ below the ground surface. In this operation, water is pumped down from injection well to stimulate the hot rock stratum. This hydraulic stimulation initiates the opening of existing fractures [1,2]. The continued pumping of water acting as stimulation fluid causes the fractures to open after which the rock faces then shift due to existing shear stress. When the fracture close back up after stimulation, the irregularities in the rock prevent them from closing completely which results in the formation of a permeable fracture flow network. After forming the reservoir, a production well is installed within the fracture's network. Then, the heat transmission fluid as the working fluid from the injection well is transported to the production well through the hot fracture zones; thereafter, it circulates between the injection- and production-wells.

During such wellbore construction, operators pay considerable attention to the preexisting fractures, and pressure-generated ones made in the underground foundation during drilling and logging. These fractures in terms of lost circulation zones often cause the wastage of a substantial amount of the circulated water-based drilling fluid or mud. To deal with this problem, operators must seal or plug the lost circulation zones with appropriate materials to avoid depleting the drilling fluid and loosing mud. Once this problem is resolved, the drilling operation can resume and continue until the wellbore structure is completed. Thereafter, the hydraulic -stimulation process begins. Next the inevitable concern is the fact that all sealing materials that were used to plug the fractures present in hydrothermal reservoir's rock stratum must be disintegrated by highly pressured water to reopen the sealed fractures and to promote the propagation of reopened fractures.

Presently, Ordinary Portland Cement (OPC) not only is used as a well-casing cementing material, but also often is adapted as the binder in the sealing systems including bridging additives like fibrous materials [3,4]. This fact suggested that in developing the ideal 
sealing binders, their potential value for use as well-casing cements also should be considered. Earlier, when the OPC-based cementitious materials were employed widely as geothermal well-casing cement, which serves in supporting mechanically the metal casing-pipe and in protecting it against corrosion, one serious drawback was their limited resistance to the hot acidic environment created by the combination of concentrated dihydrogen sulfide $\left(\mathrm{H}_{2} \mathrm{~S}\right)$ and carbon dioxide $\left(\mathrm{CO}_{2}\right)$ in geothermal wells. As well documented $[5,6]$, the capacity of OPCs to withstand acid was very poor, and they suffered from severe acid erosion. To deal with this problem, acid-resistant cements had to be developed.

In response to this need, researchers at Brookhaven National Laboratory (BNL) formulated alkali-activated cementitious materials (AACMs) that resisted acid much better than did the OPCs; this work was part of DOE's earlier geothermal program aimed at developing alternative cost-effective acid-resistant geothermal well cements $[7,8]$. The AACMs were prepared hydrothermally using two major components: One was inexpensive industrial by-products with pozzolanic properties, such as the slag from steel industries and the fly ashes from coal-combustion power plants; the other was the sodium silicate along with various mol. ratios of $\mathrm{Na}_{2} \mathrm{O} / \mathrm{SiO}_{2}$ as the alkali activators that initiate the pozzolanic reactions. Two factors contributed to minimizing acid erosion: One was the self-repairing property of the cement itself; the other was the anti-acid zeolite phase formed by the interactions between the mullite in fly ash and the $\mathrm{Na}$ ions liberated from the sodium silicate activator. From this work, we concluded that these economical AACMs have a high potential as acid-resistant geothermal well cements at temperatures up to $200^{\circ} \mathrm{C}$.

In a standpoint of the self-degradation of cementitious materials, the biodegradable biopolymers including the starch, cellulose acetate, gelatin, and poly(L-lactic acid) in the form of powder, microsphere, and fiber, are currently used as additives, which promote the partial biological degradation of biocompatible bone cements [9-12]. When these additives in the bone cements came in contact with body fluids, they are degraded to create high porosity of cements, thereby providing inter-connective channels for the bone 
tissue's growth and facilitating the resorption of cement. In addition, our interest in biopolymers was their intriguing mechanism of thermal degradation. The cellulose and cellulose-related compounds are degraded thermally in air at temperatures around $200^{\circ} \mathrm{C}$; yielding acetic acid as by-products [13-15]. This information inspired us to investigate the potential of cellulose compounds as thermal degradable additives to promote the selfdegradation of temporary cementitious sealing materials at temperatures $\geq 200^{\circ} \mathrm{C}$ after water has penetrated through the sealer.

Based upon this concept, our focus in this study centered on formulating AACMs, in particular, slag/Class C fly ash combined system, as the binder in temporary sealing material, and investigating the ability of sodium carboxymethyl cellulose (CMC) as thermal degradable additive to promote the disintegration of AACM-based sealer. CMC and cellulose-related compounds were not new materials in drilling industries. These compounds frequently are used as additives in water-based drilling mud to reduce fluid loss in mud, to confer water-holding properties on mud, and to assure its appropriate rheology at elevated temperature [16-20].

In obtaining this information, this study had the following four major objectives: First objective was to optimize the formula for blending the alkali-activated slag/Class C fly ash dry components, using data on its setting time, compressive strength, and identification of crystalline phases responsible for strengthening the sealant. The second objective focused on the thermal decomposition of CMC additive, and the chemistry of decomposed $\mathrm{CMC}$. The third one was measuring the changes in setting time, porosity, and compressive strength of optimized $\mathrm{AACM}$ as a function of $\mathrm{CMC}$ content, and also analyzing the chemical behavior of $\mathrm{CMC}$ in $\mathrm{AACM}$ in different thermal environments. The final one was to visualize the self-degradation of the CMC-modified AACM sealer and to determine in-situ exothermic energy evolved in the sealer while water penetrated through them. The integration of all information described above was directed toward understanding the self-degradation mechanism. 


\section{Experimental Procedure}

Two industrial by-products with pozzolanic properties, granulated blast-furnace slag under trade name "New Cem," and Class C fly ash, were used as the hydraulic pozzolana cement. The slag was supplied from Lafarge North America, and fly ash was obtained from Boral Material Technologies, Inc. Table 1 lists their chemical constitutions. A sodium silicate granular powder under trade name "Metos Bead 2048," supplied by The PQ Corporation, was used as the alkali activator of these pozzolana cements, and its chemical composition was 50.5 mol. wt $\% \mathrm{Na}_{2} \mathrm{O}$ and 46.6 mol. wt \% $\mathrm{SiO}_{2}$. The formula of the dry pozzolana cements employed in this test had slag/Class $\mathrm{C}$ fly ash ratios of $40 / 60,20 / 80$, and $0 / 100$ by weight. Sodium silicate powder activator of $4 \%$ by the total weight of pozzolana cement was added to prepare the dry mix cementitious reactant. For comparison purpose, the commercial Class G well cement was used as control.

The sodium carboxymethyl cellulose (CMC) was produced by etherification of cellulose from renewable resources, like wood, and had chemical structure shown in Figure 1. CMC under the production name "Walocel CRT 30 PA," supplied by Dow Chemical Corp., was used as the thermal degradable additive to promote the disintegration of the AACM-based sealers; it dissolves in water, forming an anionic polymer. A $0.4,0.7$, and $1.0 \% \mathrm{CMC}$ by total weight of dry slag/Class $\mathrm{C}$ fly ash/activator mixtures was incorporated into AACMs.

AACM slurries with and without CMC were prepared by adding an appropriate amount of water to the dry mix cementitius component, and then left them in an atmospheric environment until the cement set. Adding the $\mathrm{CMC}$ led to the entrainment of air into slurries, reflecting the formation of lightweight slurries. Afterward, the room temperature-set AACM samples were exposed in an autoclave at $200^{\circ} \mathrm{C}$ for 5 hours; some autoclaved samples then were heated for 24 hours in over at $200^{\circ}, 250^{\circ}$, and $300^{\circ} \mathrm{C}$.

\section{Measurements}

The initial- and final-setting times of CMC-incorporated and unincorporated AACM sealing slurries at $85^{\circ} \mathrm{C}$ were determined in accordance with modified ASTM C 191-92. 
In it, a slurry-filled conical mold was placed in screw-topped round glass jar to avoid any evaporation of water from slurry during heating. The slurry was examined every 30 minutes to determine its setting time. The porosity of autoclaved and heated AACMs was measured by helium pyconometry. The specimens with size, $35 \mathrm{~mm}$ diameter $\mathrm{x} 70 \mathrm{~mm}$ length were used for porosity and compressive strength testing. X-ray powder diffraction (XRD) was used to identify the phase composition of the autoclaved- and heatedsamples.

With a Type $\mathrm{K}$ thermometer, in conjunction with temperature data logger, we monitored the heat energy generated in the AACM slurries during the induction period of its hydration reactions, and also to determine the exothermic energy evolved in a selfdegrading process of the cured AACM specimens after their contact with water.

Differential scanning calorimetry (DSC) and Fourier transform infrared spectroscopy (FT-IR) give us information on the thermal decomposition and chemistry of CMC; further, we adapted FT-IR to reveal the chemical behavior of the decomposed CMC in AACM. In preparing the film sample of CMC, $1.0 \mathrm{~g}$ "as-received" CMC powder was dissolved in $200 \mathrm{~g}$ deionized water (D.I.). A certain amount of CMC solution was poured into a cell culture dish, and heated at $85^{\circ} \mathrm{C}$ for 24 hours. The resulting $\mathrm{CMC}$ film then was exposed for 24 hours in an oven at temperatures of $200^{\circ}, 250^{\circ}$, and $300^{\circ} \mathrm{C}$.

\section{Results and Discussion}

\section{Properties of Slag/Class C fly ash Blending System}

Our first experiment was directed towards gaining data on the setting time and compressive strength of AACM samples made with slag (S)/Class C fly ash (C) ratios of $40 / 60,20 / 80$, and $0 / 100$. Table 2 shows the changes in water content, expressed as the ratio of water (w) to dry cement (c), as a function of the $\mathrm{S} / \mathrm{C}$ ratio used in preparing the AACM slurries; it includes their initial- and final-setting times at $85^{\circ} \mathrm{C}$. The water content in these AACM systems was adjusted to attain a consistency similar to that of Class $\mathrm{G}$ well cement slurries made with the w/c ratio of 0.39 . As evident, the w/c ratio decreased with the replacement of some portion of slag by Class $\mathrm{C}$ fly ash. The w/c ratio 
of slurry made with $0 / 100 \mathrm{~S} / \mathrm{C}$ ratio without slag was $\sim 20 \%$ and $\sim 30 \%$ lower than that of the 40/60 S/C ratio and the Class G well cement slurries, respectively. For the latter, no initial set was apparent after exposure for $60 \mathrm{~min}$ in an oven at $85^{\circ} \mathrm{C}$, but extending the exposure time to 90 min resulted in its final set, demonstrating that both its initial- and final-setting occurred within 30 min. In contrast, all AACMs had at least 30-min interval between the initial and final settings. The elapsed time for AACM's initial setting depended on the S/C ratios; with 40/60 S/C ratio, it was $\sim 30 \mathrm{~min}$, corresponding to a 60 min shorter than that of the Class G slurries. This initial setting time extended to $\sim 60$ min when $20 \%$ of slag was replaced by Class C fly ash, beyond this, as in the $0 / 100 \mathrm{~S} / \mathrm{C}$ ratio, the fly ash was ineffective in further extending setting time. As a result, it appeared that the slag acted to accelerate the setting of slurries.

Figure 2 compares the compressive strength of the specimens made with 40/60, 20/80, and $0 / 100 \mathrm{~S} / \mathrm{C}$ ratios after exposure in four different thermal conditions, as described under Experimental Procedure. For comparison purpose, the Class G well cement also was tested under the same conditions. After autoclaving at $200^{\circ} \mathrm{C}$, the samples with a $40 / 60 \mathrm{~S} / \mathrm{C}$ ratio had a compressive strength of 5144 psi; those made with the 20/80 ratio displayed a further $\sim 16 \%$ improvement to 5981 psi. The $0 / 100$ ratio without slag was not as effective in improving strength as that of 40/60 and 20/80 ratios, strongly demonstrating that incorporating an appropriate amount of slag into Class $\mathrm{C}$ fly ash was essential in attaining the best strength in autoclaved AACMs. In contrast, the effect of autoclaving on the development of strength in commercial Class G well cement was poor, reflecting $\sim 3.8$ - and $\sim 2$.4-fold lower than that of 20/80 and 0/100 ratios, respectively. Heating the autoclaved AACMs at $200^{\circ}, 250^{\circ}$, and $300^{\circ} \mathrm{C}$ engendered a decline in compressive strength of all them that was directly related to increasing temperature. For instance, the strength of the autoclaved $20 / 80$ ratio fell $\sim 17 \%$ to 4945 psi after heating at $300^{\circ} \mathrm{C}$. There was no significant change in strength for the Class $\mathrm{G}$ cement in this temperature range.

From this result, the $20 / 80 \mathrm{~S} / \mathrm{C}$ ratio that possessed the highest compressive strength and initial setting of $\sim 60$ min was selected as matrix of sealing materials. Figure 3 depicts the 
XRD tracings for autoclaved 20/80 ratio specimens before and after heating at $300^{\circ} \mathrm{C}$, and also it includes "as-received" slag and Class C fly ash as the starting materials. For slag, XRD pattern (a) revealed the typical amorphous feature of $\mathrm{CaO}-\mathrm{Al}_{2} \mathrm{O}_{3}-\mathrm{MgO}-\mathrm{SiO}_{2}$ glass structure. The pattern (b) for Class $\mathrm{C}$ fly ash consisted of four crystalline phases, quartz $\left(\mathrm{SiO}_{2}\right)$, calcium sulfate anhydrite $\left(\mathrm{CaSO}_{4}\right)$, tricalcium aluminate $\left(3 \mathrm{CaO} \cdot \mathrm{Al}_{2} \mathrm{O}_{3}\right.$, $\left.\mathrm{C}_{3} \mathrm{~A}\right)$, and lime $(\mathrm{CaO})$. After autoclaving the sodium silicate-activated 20/80 S/C ratio specimen at $200^{\circ} \mathrm{C}$, two hydrated reaction products were formed in the cementitius body through the hydrothermal-catalyzed pozzolanic reactions (see pattern c): One was $1.1 \mathrm{~nm}$ tobermorite $\left[\mathrm{Ca}_{3}(\mathrm{OH})_{2} \mathrm{Si}_{6} \mathrm{O}_{16} \cdot 4 \mathrm{H}_{2} \mathrm{O}\right]$; the other was related to calcium silicate hydrate (I) $\left[\mathrm{CaO} \cdot \mathrm{SiO}_{2} \cdot \mathrm{H}_{2} \mathrm{O}\right.$, C-S-H (I)], while some non-reacted phases, such as $\mathrm{C}_{3} \mathrm{~A}$ and quartz attributed to the Class $\mathrm{C}$ fly ash remained. Neither calcium sulfate nor lime was detected in this pattern, seemingly suggesting that these calcium compounds were transferred to the reaction products during autoclaving. To obtain more information on the crystalline reaction products, we surveyed the phase composition of autoclaved $0 / 100 \mathrm{~S} / \mathrm{C}$ ratio without slag by XRD (Figure 4). Compared with the composition of the autoclaved 20/80 ratio, the slag-free AACM comprised poorly developed $1.1 \mathrm{~nm}$ tobermorite and C-S-H (I) phases, reflecting the weak intensity of $d$-spacing lines related to these phases. Thus, the addition of some slag to Class C fly ash in AACM system was responsible for developing well-formed tobermorite and C-S-H (I) phases, both of which improve the strength of AACM. Upon heating at $300^{\circ} \mathrm{C}$, as shown in Fig. 3, its pattern (d) revealed no changes in the composition of well-crystallized phases, compared with that of autoclaved one, suggesting that these phases formed by autoclaving withstand $300^{\circ} \mathrm{C}$ heating. Nevertheless, both well-formed tobermorite and C-S-H (I) phases were responsible for strengthening the 20/80 ratio AACM.

Next, our focus shifted to investigating the properties of CMC additive and assessing the potential of incorporating it into the 20/80 ratio AACM as a self-degradable sealer.

\section{CMC Additive}

Figure 5 gives the $\mathrm{DSC}$ curve of the $\mathrm{CMC}$ at temperatures from $100^{\circ}$ to $450^{\circ} \mathrm{C}$ in nitrogen; it encompasses two endothermic-transition peaks, $T_{p 1}$ and $T_{p 2}$, at $270^{\circ}$ and 
$304^{\circ} \mathrm{C}$. Since the endothermic peaks reflect the thermal decomposition of the samples, CMC seemingly has a two-stage decomposition process. The onset of the first stage began at $165^{\circ} \mathrm{C}$, denoted as $T_{01}$ and ended at $295^{\circ} \mathrm{C}$, marked as $T_{02}$. The second stage occurred between $295^{\circ}$ and ended of $322^{\circ} \mathrm{C}$ as $T_{e}$. To support this information, we determined the exothermic decomposition energy evolved on each stage of CMC's thermal decomposition from the closed areas of curves with the baseline. The values for the first- and second-stages were 510.8 and $53.8 \mathrm{~J} / \mathrm{g}$, respectively, meaning that the most of CMC's decomposition took place at temperatures between $165^{\circ} \mathrm{C}$ and $295^{\circ} \mathrm{C}$.

Figure 6 illustrates FT-IR spectra in the wavenumber region, 3500-700 $\mathrm{cm}^{-1}$, of CMC non-heated and heated at $200^{\circ}, 250^{\circ}$, and $300^{\circ} \mathrm{C}$ for 24 hours. Based upon the chemical structure of CMC in Figure 1 in conjunction with literature survey [21-23], the spectrum (a) of the $80^{\circ} \mathrm{C}$-made $\mathrm{CMC}$ film included several prominent absorption bands at 2925 and $2864 \mathrm{~cm}^{-1}$ associated with $\mathrm{C}-\mathrm{H}$ anti-symmetric and symmetric stretching vibrations, at $1603 \mathrm{~cm}^{-1}$ belonged to aromatic $\mathrm{C}=\mathrm{C}$ stretching mode, at 1576 $\mathrm{cm}^{-1}$ shoulder attributed to C-O anti-symmetric stretching in the carboxylate ion group, $\mathrm{COO}^{-}$, at $1400 \mathrm{~cm}^{-1}$ due to $-\mathrm{CH}_{2}$ scissoring overlapped with $\mathrm{C}-\mathrm{O}$ symmetric stretching in $-\mathrm{COO}^{-}$, at $1329 \mathrm{~cm}^{-1}$ related to both $-\mathrm{CH}_{2}$ scissoring and $\mathrm{C}-\mathrm{OH}$ bending, at $1157 \mathrm{~cm}^{-1}$ referred to $\mathrm{C}-\mathrm{O}-\mathrm{C}$ stretching in the ether group, and both at 1057 and $1020 \mathrm{~cm}^{-1}$ assignable to $\mathrm{C}-\mathrm{O}$ stretching in $>\mathrm{CH}-\mathrm{O}-\mathrm{CH}_{2}$ - linkage. Compared with this, FT-IR spectrum (b) of the $200^{\circ} \mathrm{C}$-heated CMC film was characterized by declining the band intensity at 1329,1057 , and $1020 \mathrm{~cm}^{-1}$, and disappearing the band at $1157 \mathrm{~cm}^{-1}$, demonstrating that heating the $\mathrm{CMC}$ at $200^{\circ} \mathrm{C}$ entailed the breakage and rupture of several linkages, such as $\mathrm{C}-\mathrm{OH}, \mathrm{C}-\mathrm{O}-\mathrm{C}$, and $>\mathrm{CH}-\mathrm{O}-\mathrm{CH}_{2}-$ within $\mathrm{CMC}$ 's molecular structure. Further increasing temperature to $250^{\circ} \mathrm{C}$ led to the incorporation of five new bands at $1685,1457,879,835$, and $780 \mathrm{~cm}^{-1}$ into the spectrum (c). The possible contributors to these new bands at 1685 and $1457 \mathrm{~cm}^{-1}$ were the carbonyl, $\mathrm{C}=\mathrm{O}$, in ketone species formed by intra-ring dehydration [24] and a carbonated compound like sodium carbonate, $\mathrm{Na}_{2} \mathrm{CO}_{3}[25]$, respectively. The other new bands emerging in low wavernumber region $<900 \mathrm{~cm}^{-1}$ might be associated with the organic fragments yielded by thermal degradation of CMC. This spectrum also strongly represented that the band at 
$1576 \mathrm{~cm}^{-1}$ attributed to $-\mathrm{COO}^{-}$ionic group had become one of the major peaks, while the aromatic- and $>\mathrm{CH}-\mathrm{O}-\mathrm{CH}_{2}$ - linkage-related bands had vanished. Thus, the thermal decomposition of $\mathrm{CMC}$ at $250^{\circ} \mathrm{C}$ seemingly generates many $-\mathrm{COO}^{-}$groups that are converted into organic acid in an aqueous media. Several investigators $[13,15]$ reported that this thermal decomposition generated volatile decomposition products, such as $\mathrm{CO}$, $\mathrm{CO}_{2}, \mathrm{CH}_{4}$, water, and acetic acid. Among those, the major decomposition product at $250^{\circ} \mathrm{C}$ was acetic acid, which occupies more than $40 \%$ of its total amount. This information strongly supported the likelihood of $-\mathrm{COO}^{-} \rightarrow$ organic acid transformation as well as the formation of sodium carbonate from the interactions between two decomposition by-products of $\mathrm{CMC}$, sodium oxide and $\mathrm{CO}_{2}$. At $300^{\circ} \mathrm{C}$, the spectrum (d) revealed the incorporation of more $\mathrm{C}=\mathrm{O}$ group and $\mathrm{Na}$ carbonate into the thermally degraded CMC, as reflected in the pronounced growth of bands at 1685 and $1457 \mathrm{~cm}^{-1}$ coexisting with the new band at $849 \mathrm{~cm}^{-1}$ attributed to carbonate.

\section{CMC-incorporated 20/80 S/C Ratio AACM}

Figure 7 shows the changes in temperature of the 20/80 S/C ratio AACM and Class G cement slurries within $530 \mathrm{sec}$ after mixing with water. Shortly after mixing dry AACM with water, its temperature rose from $21^{\circ} \mathrm{C}$ to $24^{\circ} \mathrm{C}$, and continuously increased until it leveled at $27.5^{\circ} \mathrm{C}$ after $290 \mathrm{sec}$. This rapid rise was due to the dissolution of the sodium silicate activator in an aqueous media. As expected, Class G cement slurry doesn't generate any heat in such a short hydration period.

Table 3 lists the water-to-cement (w/c) ratios and the initial- and final-setting times at $85^{\circ} \mathrm{C}$ for Class $\mathrm{G}$ well cement and $20 / 80 \mathrm{~S} / \mathrm{C}$ ratio AACM modified with $0.4,0.7$, and 1.0 $\mathrm{wt} \% \mathrm{CMC}$. In both the cement systems, the w/c ratio increased with an increasing CMC content, from 0.39 at $0 \% \mathrm{CMC}$ to 0.62 at $1.0 \% \mathrm{CMC}$ for Class $\mathrm{G}$ cement, and from 0.31 at $0 \% \mathrm{CMC}$ to 0.52 at $1.0 \% \mathrm{CMC}$ for $\mathrm{AACM}$. Adding the $\mathrm{CMC}$ to the Class $\mathrm{G}$ cement remarkably prolonged its setting time; in fact, the value of initial setting time without CMC was extended by nearly $210 \mathrm{~min}$ to $\sim 300 \mathrm{~min}$ after incorporating $0.4 \% \mathrm{CMC}$. Correspondingly, adding more than $0.4 \%$ CMC considerably delayed the hydration of cement so there was no evidence of initial setting time within $360 \mathrm{~min}$. Undoubtedly, 
$\mathrm{CMC}$ acted as set retarder of Class $\mathrm{G}$ cement. In contrast, $\mathrm{CMC}$ was not as effective in retarding the setting of AACM. All 20/80 S/C ratio AACM modified with CMC were set for curing period up to $210 \mathrm{~min}$. With $0.4 \% \mathrm{CMC}$, both the initial- and final-setting times of CMC-free AACM were prolonged by 30 min to $\sim 90$ and $\sim 120$ min. Further increasing amount to $0.7 \%$ led to the extension of another 30 and 60 min of initial- and final-setting times over that of $0.4 \%$. Nevertheless, at the room temperature of $\sim 25^{\circ} \mathrm{C}$, the final setting of both the Class G and AACM specimens was observed within 30 hours after mixing with water.

Figures 8 and 9 give the changes in compressive strength of AACM and Class G cement exposed in the four different thermal environments described earlier as a function of $\mathrm{CMC}$ content. For AACM, the strength for all specimens exposed to all different environments fell with increasing CMC content; in particular, the addition of the first 0.4 $\% \mathrm{CMC}$ resulted in a remarkable decline in strength, ranging from 42-60\%, compared with that of CMC-free specimens; beyond this content, strength fell monotonously. However, despite adding a high CMC content of 1\%, all specimens, except for those heated at $300^{\circ} \mathrm{C}$, retained a compressive strength of more than 1000 psi. A similar trend was observed from Class $\mathrm{G}$ cement, namely, the strength decreased with an increasing CMC content. In fact, the compressive strength values, ranging from 1594 to 1475 psi, for all $\mathrm{CMC}$-free specimens fell to less than $1000 \mathrm{psi}$ when $\geq 0.7 \% \mathrm{CMC}$ was added.

Figures 10 and 11 plot the porosity vs. CMC content for the AACM and Class G cement after expose to different heat treatment conditions. For AACM, after drying autoclaved specimens without $\mathrm{CMC}$ for 24 hours at $85^{\circ} \mathrm{C}$, their porosity was $12.5 \%$. This value increased by $\sim 2.3$ times to $\sim 29.0 \%$ when the specimens were heated in the temperature range from $200^{\circ}$ to $300^{\circ} \mathrm{C}$. As described earlier, XRD study revealed that the crystalline phase composition of autoclaved AACM after heating at $300^{\circ} \mathrm{C}$ closely resembled that of non-heated one. Thus, the increased porosity after heat treatment is more likely to be associated with the elimination of a certain amount of free water linked to the cementitious matrix, rather than the dehydration of crystalline hydration products as the hydrothermal reaction products. In heated CMC-containing AACM systems, CMC 
dramatically impacted in creating the porous cementitioius structure. Adding $0.4 \% \mathrm{CMC}$ resulted in the formation of AACM having the porosity $>40 \%$. Further, raising the temperature promoted the incorporation of more voids into the AACM. Both autoclaved and heated AACMs amended with $1 \%$ CMC displayed a porosity of more than $50 \%$. For Class $\mathrm{G}$ cement, $\mathrm{CMC}$-free autoclaved cement had a porosity of $35.5 \%$, and this value rose to $\sim 40 \%$ by heating at $200^{\circ}-300^{\circ} \mathrm{C}$. Like CMC-modified AACM, adding $\mathrm{CMC}$ to Class $\mathrm{G}$ caused the incorporation of more voids into cement structure, while the increase in heating temperature engendered the incorporation of additional voids.

As mentioned in the Experiment Procedure and discussed in Table 3, CMC was responsible for an air entrainment and an increase in water/cement ratio of AACM that assured the constant consistency of cement slurries. Thus, there were two possible reasons for the creation of porous structure: One was the incorporation of air into the AACM's slurries; the other was the increased water content of the slurries. To elucidate fully the role of $\mathrm{CMC}$ in increasing the porosity, we analyzed $1.0 \% \mathrm{CMC}$-modified $20 / 80 \mathrm{~S} / \mathrm{C}$ ratio specimens by FT-IR. All specimens were dried in an oven at $85^{\circ} \mathrm{C}$ for 24 hours before analyzing them. The "as-received" slag and Class C fly ash were also used as references. Figure 12 illustrates the FT-IR spectra of these references; for slag, the spectrum had three prominent bands at $\sim 2923 \mathrm{~cm}^{-1}, \sim 1620 \mathrm{~cm}^{-1}$, and $\sim 1430 \mathrm{~cm}^{-1}$, and one wide band in the range of 1050 to $820 \mathrm{~cm}^{-1}$. The first two bands are associated with water adsorbed into cementitious body, while the third band is due to the carbonated compounds. In contrast, no carbonation product was found in Class $\mathrm{C}$ fly ash. Figure 13 compares the spectral features of specimens made under the room temperature for 24 hours and under four different conditions. The spectrum (a) of the room temperaturecured specimen, followed by heating at $80^{\circ} \mathrm{C}$ had CMC-related bands at 1597,1405 , and $1354 \mathrm{~cm}^{-1}$ in conjunction with that from carbonates at $1450 \mathrm{~cm}^{-1}$, and from water at 2923 , 2853 , and $1627 \mathrm{~cm}^{-1}$. Similar spectral feature, except for the appearance of carbonaterelated band at $1420 \mathrm{~cm}^{-1}$, was obtained from specimen autoclaved at $200^{\circ} \mathrm{C}$ for 5 hours (b), strongly suggesting that CMC didn't decompose in such a lengthy hydrothermal environment. In comparison, the features of $200^{\circ} \mathrm{C}$-heated specimen (c) was different; in particular, the elimination of all CMC-related bands and the marked growth of band at 
$1420 \mathrm{~cm}^{-1}$. As discussed in the DSC study of CMC, the thermal degradation of CMC begun at $165^{\circ} \mathrm{C}$, subsequently, causing the emission of $\mathrm{CO}_{2}$. Hence, it is reasonable to consider that the in-situ dry carbonation reactions between the $\mathrm{CO}_{2}$ and alkaline earth metals, like $\mathrm{Ca}$ from slag and Class $\mathrm{C}$ fly ash or alkaline metals like $\mathrm{Na}$ from $\mathrm{CMC}$ occurred in cementitious bodies during heating, and lead to the formation of carbonation products, such as $\mathrm{CaCO}_{2}$ and $\mathrm{Na}_{2} \mathrm{CO}_{3}$. At $250^{\circ}$ (d) and $300^{\circ} \mathrm{C}$ (e), their spectral features closely resembled to that of $200^{\circ} \mathrm{C}$. Accordingly, we conclude that the generation of gasses phase emitted by thermal degradation of CMC was the other factor governing the increase in porosity of AACMs.

\section{Self-degradation and Its Mechanism}

We questioned whether CMC-modified AACM really degrades after contacting with water. In respond to this question, two different tests were conducted to visualize its selfdegradation: One test was directly to immerse hot 20/80 S/C ratio AACM and Class G cement modified and unmodified with $\mathrm{CMC}$ into water at $25^{\circ} \mathrm{C}$; the other was to impregnate water into the air-free CMC-modified and unmodified 20/80 ratio AACM and Class G cement specimens. The detailed test procedures were as follows; for the fist test, 1) the specimens was autoclaved at $200^{\circ} \mathrm{C}$ for 5 hours, and then heating at $200^{\circ} \mathrm{C}$ for 24 hours, 2) shortly after removing hot specimens form an oven, they were immersed in the water at $25^{\circ} \mathrm{C}$, and 3) visual observation allowed us to evaluate the magnitude of its selfdegradation. For the second test, 1) the specimens were autoclaved at $200^{\circ} \mathrm{C}$ for 5 hours, and then heated at $200^{\circ} \mathrm{C}$ for 24 hours, 2) the specimens were cooled for 24 hours at room temperature, 3 ) thermocouple-embedded specimens were placed in a vacuum chamber at $-1000 \mathrm{kPa}$ for $10 \mathrm{~min}$ to eliminate any air present in the specimens, 4) air-free voids in the vacuumed specimens were filled with water (water/specimens volume ratio= 17/1), while determining the generation of in-situ exothermic heat by temperature data logger, and 5) visual observation was made to evaluate the magnitude of self-degradation.

For the first test, figure 14 shows the appearance of $200^{\circ} \mathrm{C}$-heated $20 / 80$ ratio AACMs containing $0,0.4,0.7$, and $1.0 \% \mathrm{CMC}$ after the immersing them in water at $25^{\circ} \mathrm{C}$. Shortly after immersion, we observed the development of numerous cracks in all CMC-modified 
AACMs. Furthermore, the propagation of cracks with elapsed immersion time led to their disintegration. We visually observed that AACMs modified with CMC of $\geq 0.7 \%$ seem to generate a large number of wider crack, compared to specimens with $0.4 \% \mathrm{CMC}$, emphasizing that the higher concentration of CMC promoted more self-degradation in AACM. In contrast, CMC-free AACM showed no signs of degradation. We noted a similar magnitude of degradation in CMC-modified AACMs heated at $250^{\circ}$ and $300^{\circ} \mathrm{C}$ (data not shown).

In contrast, incorporating CMC into the Class G cement didn't affect degradation; there was no development of any cracks. This information strongly demonstrated that CMC conferred potential self-degrading properties on AACM, but not on commercial Class G well cement. A possible interpretation for this fact was that when the water was permeated into AACM containing thermally decomposed $\mathrm{CMC}$, it served in disintegrating the hard cementitious structure possessing a compressive strength of more than 2000 psi. Conceivably, such disintegration by water may be due to the generation of water-catalyzed energy in AACM. If this assumption is valid, two resources were involved, one from AACM, and the other from the decomposed CMC.

To verify this assumption, next, our attention turned to the finding from the second test, i.e., determining the exothermic heat energy generated in AACM by water penetration. Plotting the relation curve between the elapse time and exothermic temperature for $0.7 \%$ CMC-modified AACM in Figure 15 shows that $~ 130 \mathrm{sec}$ after impregnating the vacuumed specimen with water, its internal temperature rapidly rose from $22.2^{\circ} \mathrm{C}$ to a peak of $41.5^{\circ} \mathrm{C}$. The total elapsed time from the onset to the maximum temperature was only $110 \mathrm{sec}$. We observed the development of numerous cracks in the waterimpregnated specimens along with the increase in their exothermic temperature. Hence, the penetration of water through the specimen led to the evolution of in-situ exothermic heat promoting the self-degradation of the sealer. Figure 16 plots the peak temperature of heat energy generated in the AACM and Class G cement specimens containing 0, 0.4, 0.7, and $1.0 \%$ CMC. For AACM, although the specimen does not have any CMC, the uptake of water generated some degree of in-situ heat; in fact, specimen's original 
temperature of $22.2^{\circ} \mathrm{C}$ rose to $32.6^{\circ} \mathrm{C}$ after impregnation. As we noted earlier, the dissolution of the sodium silicate activator in an aqueous media evolves heat. Correspondingly, this rise in temperature primarily was caused by the re-dissolution or dissolution of partially dissolved or non-dissolved sodium silicate activator remained in the $200^{\circ} \mathrm{C}$-heated AACM after water uptake. Of particular interest was the further increase in internally generated heat when $\mathrm{CMC}$ was added to it. With $0.4 \% \mathrm{CMC}$, the exothermic temperature rose by $8^{\circ} \mathrm{C}$ to $40^{\circ} \mathrm{C}$. Incorporating more $\mathrm{CMC}$ further enhanced its internal temperature. As is seen in Figure 16, the magnitude of self-degradation depended on the exothermic heat generated, which corresponded to CMC content; a high exothermic temperature severely decomposed the sealing material.

In contrast, no internal heat energy was produced in Class G cements modified with $\mathrm{CMC}$; accordingly, the specimens remained intact in terms of non-self degradation.

Integrating all these data, we propose the self-degradation mechanism of CMC-modified AACM depicted in Figure 17, as follows. Although our study provide limited information on the hydrothermal degradation of CMC, no degradation of CMC additive was found in AACM body after autoclaving at $200^{\circ} \mathrm{C}$ for 5 hours. In the first step of selfdegradation routs, when the autoclaved sealing material was heated at temperatures of $\geq$ $200^{\circ} \mathrm{C}$, the $\mathrm{CMC}$ in the AACM thermally decomposed, yielding five reactants, $\mathrm{CO}_{2}, \mathrm{CO}$, $\mathrm{CH}_{4}, \mathrm{CH}_{3} \mathrm{COOH}$, and $\mathrm{Na}_{2} \mathrm{CO}_{3}$. In the second step, the penetration of water through AACM triggered the dissolution of non-reacted or partially reacted sodium silicate activator to release sodium hydroxide, $\mathrm{NaOH}$, as hydrolysate. The sodium silicate next reacted with ionic carbonic acid, $\mathrm{CO}_{3}{ }^{2-}$ and $2 \mathrm{H}^{+}$, known as wet carbonation to form sodium bicarbonate, $\mathrm{NaHCO}_{3}$. In a final step, sodium bicarbonate favorably reacted with acetic acid, $\mathrm{CH}_{3} \mathrm{COOH}$, from $\mathrm{CMC}$ to yield three reaction products, sodium acetate, carbon dioxide, and water. This exothermic reaction is very similar to that between baking soda and vinegar well known as the "volcanic reaction." Thus, the emission of carbon dioxide evolved from this reaction might expand the volume of cementitious structure, promoting its in-situ degradation. On the other hand, the sodium carbonate derived from thermal decomposition of $\mathrm{CMC}$ might undergo wet carbonation, $\mathrm{Na}_{2} \mathrm{CO}_{3}+$ 
$\mathrm{CO}_{3}{ }^{2-}+2 \mathrm{H}^{+} \rightarrow 2 \mathrm{NaHCO}_{3}$. However, the total amount of $\mathrm{NaHCO}_{3}$ yielded from this wet carbonation, if any, was very small, and insufficient to degrade the cementitious structure by its following reaction with $\mathrm{CH}_{3} \mathrm{COOH}$. The other possibility for promoting the selfdegradation was the acid-base exothermic reactions between sodium hydroxide and acetic acid.

\section{Conclusion}

An alkali-activated cementitious material (AACM) consisting of $3 \mathrm{wt} \%$ sodium silicate $\left(\mathrm{Na}_{2} \mathrm{O} / \mathrm{SiO}_{2}=1.08 \mathrm{~mol}\right.$. ratio), $14.7 \mathrm{wt} \%$ slag, $59.3 \mathrm{wt} \%$ Class $\mathrm{C}$ fly ash, and $23 \mathrm{wt} \%$ water was selected from among several candidate formulas, and its properties were compared with commercial Class G well cement to evaluate its a potential as matrix of temporary, self-degradable cementitous sealers. At $85^{\circ} \mathrm{C}, \mathrm{AACM}$ slurry had initial- and final-setting times of $\sim 60 \mathrm{~min}$ and $\sim 90 \mathrm{~min}$, respectively, and developed a compressive strength of 5981 psi after autoclaving for 5 hours at $200^{\circ} \mathrm{C}$. This value was 3.8 -fold higher than that of Class G well cement autoclaved at the same temperature. Two wellformed crystalline phases, $1.1 \mathrm{~nm}$ tobermorite and calcium silicate hydrate (I), were responsible for developing this excellent compressive strength. Exposing autoclaved $\mathrm{AACM}$ in an air-oven at temperatures from $200^{\circ}$ to $300^{\circ} \mathrm{C}$ caused a slight decline in its compressive strength with an increasing temperature. However, at $300^{\circ} \mathrm{C}$, its compressive strength still remained at nearly 5000 psi, and these crystalline phases formed in autoclaved AACM were intact.

Sodium carboxymethyl cellulose (CMC) powder was employed as a self-degradation promoting additive of AACM. A 0.4, 0.7, and $1.0 \%$ CMC was incorporated into dry mix AACM. The thermal decomposition of $\mathrm{CMC}$ began at $165^{\circ} \mathrm{C}$, and was completed at $322^{\circ} \mathrm{C}$. At $\geq 200^{\circ} \mathrm{C}$, its decomposition generated five by-products, $\mathrm{CO}_{2}, \mathrm{CO}, \mathrm{CH}_{4}$, $\mathrm{CH}_{3} \mathrm{COOH}$, and $\mathrm{Na}_{2} \mathrm{CO}_{3}$. However, the CMC in AACM didn't decompose during autoclaving for 5 hours at $200^{\circ}$, suggesting that the thermal behavior of $\mathrm{CMC}$ in a hydrothermal environment differed from that in a dry-heat environment. Adding CMC changed the properties of AACM and Class G well cement; it prolonged their initial- and final-setting times, reduced compressive strength, and increased their porosity. In the first 
case, $\mathrm{CMC}$ acted as a setting retarder; for $\mathrm{AACM}, 0.4 \% \mathrm{CMC}$ extended its initial- and final-setting time to $\sim 90 \mathrm{~min}$ from $\sim 60 \mathrm{~min}$ and to $\sim 120 \mathrm{~min}$ from $\sim 90 \mathrm{~min}$, respectively. For Class $\mathrm{G}$ well cement, CMC was unsuitable as an additive; with $0.4 \%$ $\mathrm{CMC}$, the cement slurry didn't set within $360 \mathrm{~min}$ at $85^{\circ} \mathrm{C}$. Regarding the increase in porosity, three factors operated in creating porous structure in AACM and led to a decline in compressive strength: First was the entrainment of air into slurries by CMC, second was an increase in water/cement ratio as a function of the $\mathrm{CMC}$ content; and third was the greater emission of gas by-products, such as $\mathrm{CO}_{2}, \mathrm{CO}, \mathrm{CH}_{4}$ with an increasing $\mathrm{CMC}$ content.

When CMC-incorporated AACM heated at temperatures $\geq 200^{\circ} \mathrm{C}$ came in contact with water, the water penetrating through it played pivotal role in promoting the selfdegradation of AACM. There were two important roles: One was the dissolution of nonreacted and partially reacted sodium silicate activator remaining in the AACM, reflecting the release of sodium hydroxide as reactant; the other was the formation of ionic carbonic acid from wet carbonation of $\mathrm{CO}_{2}$ deduced from thermal degradation of CMC. The sodium hydroxide released reacted directly with ionic carbonic acid to form sodium bicarbonate. Then, the chemical affinity of sodium bicarbonate with $\mathrm{CH}_{3} \mathrm{COOH}$ from the decomposed $\mathrm{CMC}$ led to the evolution of $\mathrm{CO}_{2}$ as reaction product. In-situ exothermic energy was generated throughout this process, including dissolution, interactions, and evolution. Nevertheless, we consider that this in-situ $\mathrm{CO}_{2}$ gas evolution led to volume expansion of AACM, thereby resulting in the breakage and disintegration of AACM possessing a compressive strength of more than 2000 psi. In contrast, no self-degradation was noted from CMC-containing Class $\mathrm{G}$ well cement. 


\section{References}

1. T. Kohl and T. Megel, In. J. Rock Mecha. Minn.Sci., "Predictive modeling of reservoir response to hydraulic stimulations a the European EGS site Soultz-sousForets", 44 (2007) 1118-1131.

2. S. Portier, F. Vuataz, P. Nami, B. Sanjuan, and A. Gerard, "Chemical stimulation techniques for geothermal wells: experiments on the three-well EGS system at Soultz-sous-Forets, France", Geothermic, 38 (2009) 349-359.

3. F. Fabbri and M. Vidali, "Drilling mud in geothermal wells," Geothermic, 2 (1970) 735-741.

4. T. Sugama, L.E. Kukacka, B. Galen, and N.B. Milstone, "Characteristics of high temperature cementitious lost-circulation control materials for geothermal wells," J. Mater. Sci. 22, (1987) 63-75.

5. J.H.P. Van and S. Visser, "Influence of alkali on the sulphate resistance of ordinary Portland cement mortars," Cem. Conc. Res. 15, (1985) 485-494.

6. E.F. Irassar, V.L. Bonavetti, and M. Gonzalez, "Microstructural study of sulfate attack on ordinary and limestone Portland cements at ambient temperature," Cem. Conc. Res. 33, (2003) 31-41.

7. T. Sugama and L. Brothers, "Sodium-silicate-activated Slag for Acid-resistant Geothermal Well Cements," J. Adv. in Cem. Res. 16, (2004) 77-87.

8. T. Sugama, L. Brothers, and T. Van de Putte, "Acid-resistant Cements for Geothermal Wells: Sodium Silicate Activated Slag/Fly Ash Blends," J. Adv. in Cem. Res. 17, (2005) 65-75.

9. I. Espigares, C. Elvira, J.F. Mano, B. Vazquez, J. San Roman, and R.L. Reis, New partially degradable and bioactive acrylic bone cements based on starch blends and ceramic fillers, Biomaterials, 23 (2002) 1883-1895.

10. L.F. Boesel, S.C.P. Cachinho, M.H.V. Fernands, and R.L. Reis, The in vitro bioactivity of two novel hydrophilic, partially degradable bone cements, Acta Biomaterialia, 3 (2007) 175-182. 
11. Y. Zuo, F.Yang, J.G.C. Wolka, Y. Li, and J.A. Jansen, Incorporation of biodegradable electrospun fibers into calcium phosphate cement for bone regeneration, Acta Biomaterialia, 6 (2010) 1238-1247.

12. W.J.E.M. Habraken, H.B. Liao, Z. Zhang, J.G.C. Wolke, D.W. Grijpma, A.G. Mikos, J. Feijen, and J.A. Jansen, In vivo degradation of calcium phosphate cement incorporated into biodegradable microspheres, Acta Biomaterialia, 6 (2010) 2200-2211.

13. R.M. Aseyeva, T.N. Kolosova, S.M. Lomakin, Y.Y. Libonas, G.Y. Zaikov, and V.V. Korshak, Thermal degradation of cellulose diacetate, Polym. Sci. U.S.S.R., 27 (1985) 1917-1926.

14. P. Jandura, B. Riedl, and B.V. Kokta, Thermal degradation behavior of cellulose fibers partially esterified with some long chain organic acids, Polym. Degrad. Stab., 70 (2000) 387-394.

15. M. da Conceical, C. Lucena, A.E.V. de Alencar, S.E. Mazzeto, S. de A. Soares, The effect of additives on the thermal degradation of cellulose acetate, Polym. Degrad. Stab., 80 (2003) 149-155.

16. F. Farbbri and M. Vidali, Drilling mud in geothermal wells, Geothermic, 2 (1970) 735-741.

17. A.L. Alldredge, M. Elias, and C.C. Gotschalk, Effects of drilling mud and mud additives on the primary production of natural assemblages of marine phytoplankton, Marine Envi. Res., 19 (1986) 157-176.

18. I.S. Dairanieh and S.M. Lahalih, Novel polymeric drilling and viscosifiers, Eur. Polym. J., 24 (1988) 831-835.

19. M. Amanullah and L. Yu, Environment friendly fluid loss additives to protect the marine environment from the detrimental effect of mud additives, J. Petro. Sci. Eng., 48 (2005) 199-208.

20. M. Dolz, J. Jimenez, M.J. Hernandez, J. Delegido, and A. Casanovas, Flow and thixotropy of non-contaminating oil drilling fluids formulated with bentonite and sodium carboxymethyl cellulose, J. Petro. Sci. Eng., 57 (2007) 294-302. 
21. S. Soares, N.M.P.S. Ricardo, S. Jones, and F. Heatley, High temperature thermal degradation of cellulose in air studied using FT-IR and ${ }^{1} \mathrm{H}$ and ${ }^{13} \mathrm{C}$ solid-state NMR, Euro. Polym. J., 37 (2001) 737-745.

22. V. Pushpamalar, S.J. Langford, M. Ahmad, and Y.Y. Lim, Optimization of reaction conditions for preparing carboxymethy cellulose from sago waste, Carbohydrate Polym., 64 (2006) 312-318.

23. H. Jin, Q. An, Q. Zhao, J. Qian, and M. Zhu, Pervaporation dehydration of ethanol by using polyelectrolyte complex membranes based on poly(N-ethyl-4vinylpyridinium bromide) and sodium carboxymethyl cellulose, J. Membr. Sci., 347 (2010) 183-192.

24. J. Scheirs, G. Camino, and W. Tumiatti, Overview of water evaluation during the thermal degradation of cellulose, Eur. Polym. J., 37 (2001) 933-942.

25. L.J. Bellamy, The infra-red spectra of complex molecules, pp. 385-387, Third editions, 1975, published by Chapman and Hall Ltd. 
Table 1. Chemical composition of Ground Granulated Blastfurnace Slag and Class C fly ash.

\begin{tabular}{|l|l|l|l|l|l|l|l|l|l|l|}
\hline & $\begin{array}{l}\mathbf{C a O}, \\
\mathbf{w t} \%\end{array}$ & $\begin{array}{l}\mathbf{S i O}_{2}, \\
\mathbf{w t} \%\end{array}$ & $\begin{array}{l}\mathbf{A l}_{2} \mathbf{O}_{3}, \\
\mathbf{w t} \%\end{array}$ & $\begin{array}{l}\mathbf{M g O}, \\
\mathbf{w t} \%\end{array}$ & $\begin{array}{l}\mathbf{F e}_{2} \mathbf{O}_{3}, \\
\mathbf{w t} \%\end{array}$ & $\begin{array}{l}\mathbf{T i O}_{2}, \\
\mathbf{w t \%}\end{array}$ & $\begin{array}{l}\mathbf{N a}_{2} \mathbf{O}, \\
\mathbf{w t \%}\end{array}$ & $\begin{array}{l}\mathbf{K}_{2} \mathbf{O}, \\
\mathbf{w t} \%\end{array}$ & $\begin{array}{l}\mathbf{S O}_{3}, \\
\mathbf{w t} \%\end{array}$ & $\begin{array}{l}\text { Loss in } \\
\text { ignition } \\
\text { for C, } \\
\text { wt\% }\end{array}$ \\
\hline Slag & 38.5 & 35.2 & 12.6 & 10.6 & 1.1 & 0.4 & - & - & 0.1 & 1.5 \\
\hline $\begin{array}{l}\text { Class } \\
\text { C fly } \\
\text { ash }\end{array}$ & 25.6 & 36.2 & 19.1 & 5.4 & 6.7 & - & 1.7 & 0.5 & 1.7 & 3.1 \\
\hline
\end{tabular}

Table 2. Water/cement ratio, and initial and final setting times at $85^{\circ} \mathrm{C}$ for slurries made with various $\mathrm{S} / \mathrm{C}$ ratios and Class $\mathrm{G}$ well cement.

\begin{tabular}{|l|l|l|l|}
\hline & $\begin{array}{l}\text { Water/cement, w/c, } \\
\text { ratio }\end{array}$ & $\begin{array}{l}\text { Initial setting time at } \\
85^{\circ} \mathrm{C}, \text { min }\end{array}$ & $\begin{array}{l}\text { Final setting time at } \\
85^{\circ} \mathrm{C}, \text { min }\end{array}$ \\
\hline Class G well cement & 0.39 & $\sim 90$ & $\sim 90$ \\
\hline $40 / 60 \mathrm{~S} / \mathrm{C}$ & 0.34 & $\sim 30$ & $\sim 60$ \\
\hline $20 / 80 \mathrm{~S} / \mathrm{C}$ & 0.31 & $\sim 60$ & $\sim 90$ \\
\hline $0 / 100 \mathrm{~S} / \mathrm{C}$ & 0.27 & $\sim 60$ & $\sim 90$ \\
\hline
\end{tabular}

Table 3. Changes in water/cement ratio, and initial- and final-setting times of 20/80 S/C ratio AACM and Class $\mathrm{G}$ well cement as a function of $\mathrm{CMC}$ content.

\begin{tabular}{|l|l|l|l|l|}
\hline \multirow{2}{*}{} & $\begin{array}{l}\text { CMC content, } \\
\mathrm{wt} \%\end{array}$ & $\begin{array}{l}\text { Water/cement, } \\
\mathrm{w} / \mathrm{c}, \text { ratio }\end{array}$ & $\begin{array}{l}\text { Initial setting } \\
\text { time at } 85^{\circ} \mathrm{C}, \\
\mathrm{min}\end{array}$ & $\begin{array}{l}\text { Final setting } \\
\text { time at } 85^{\circ} \mathrm{C}, \\
\mathrm{min}\end{array}$ \\
\hline \multirow{2}{*}{$\begin{array}{l}\text { Class G well } \\
\text { cement }\end{array}$} & 0 & 0.39 & $\sim 90$ & $\sim 90$ \\
\cline { 2 - 5 } & 0.4 & 0.48 & $\sim 300$ & $>360$ \\
\cline { 2 - 5 } & 0.7 & 0.54 & $>360$ & \\
\cline { 2 - 6 } & 1.0 & 0.62 & $>360$ & \\
\hline $\begin{array}{l}20 / 80 \text { S/C ratio } \\
\text { AACM }\end{array}$ & 0 & 0.31 & $\sim 60$ & $\sim 90$ \\
\cline { 2 - 6 } & 0.4 & 0.38 & $\sim 90$ & $\sim 120$ \\
\cline { 2 - 6 } & 0.7 & 0.49 & $\sim 120$ & $\sim 180$ \\
\cline { 2 - 5 } & 1.0 & 0.52 & $\sim 120$ & $\sim 210$ \\
\hline
\end{tabular}




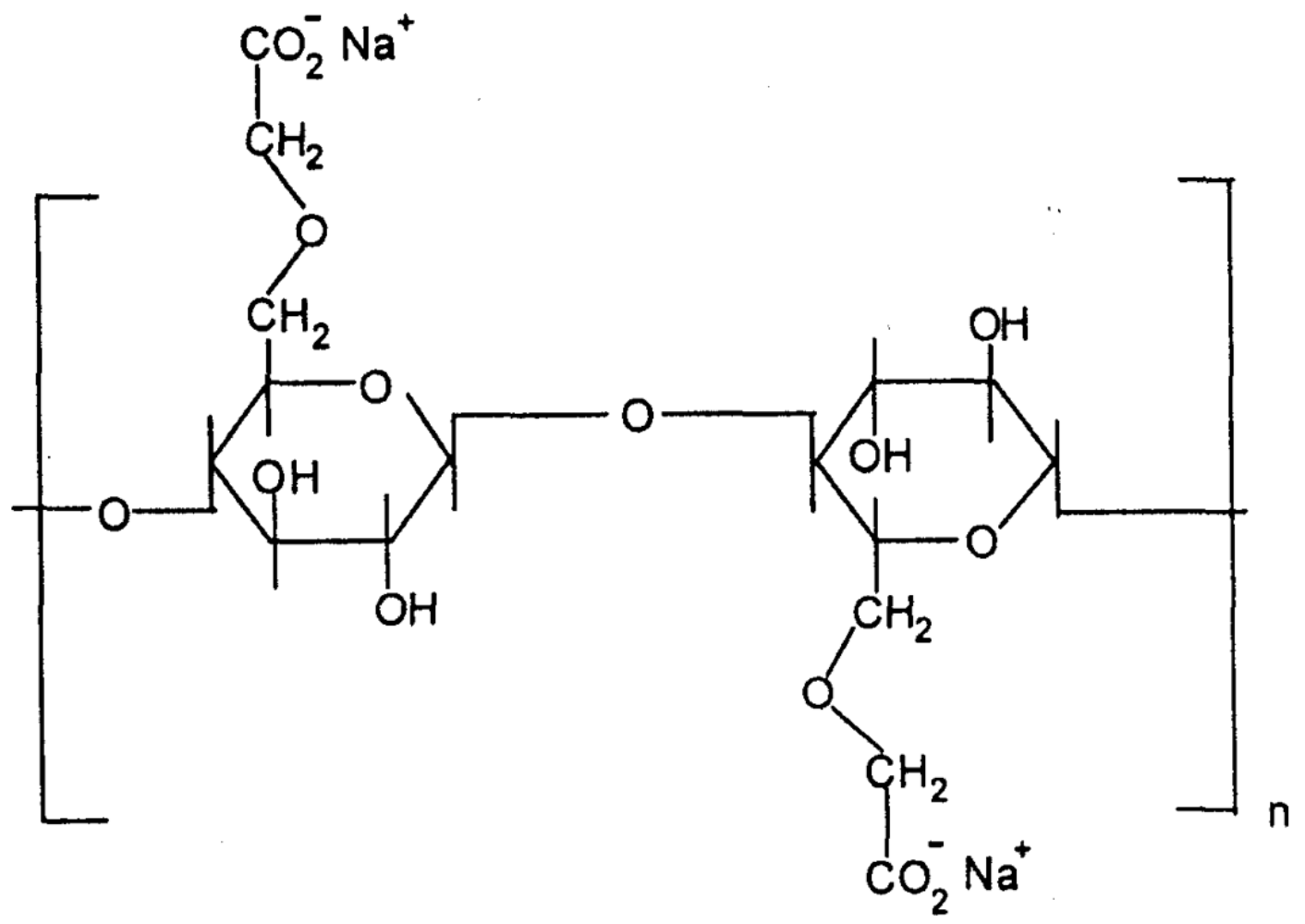

Figure 1. Chemical structure of CMC. 


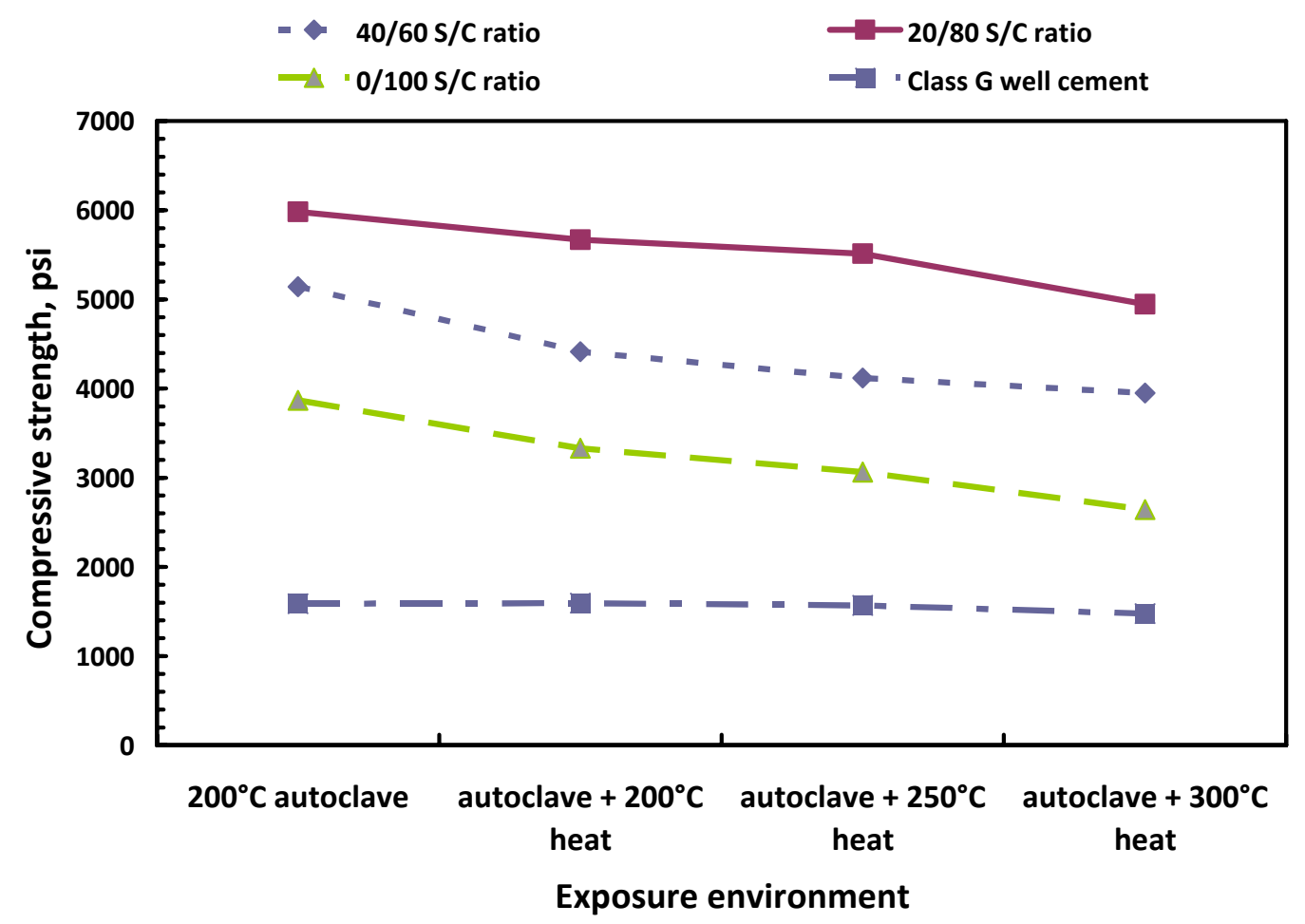

Figure 2. Compressive strength of the specimens made with 40/60, 20/80, and 0/100 S/C ratios and Class $\mathrm{G}$ well cement after exposure in four different thermal environments. 


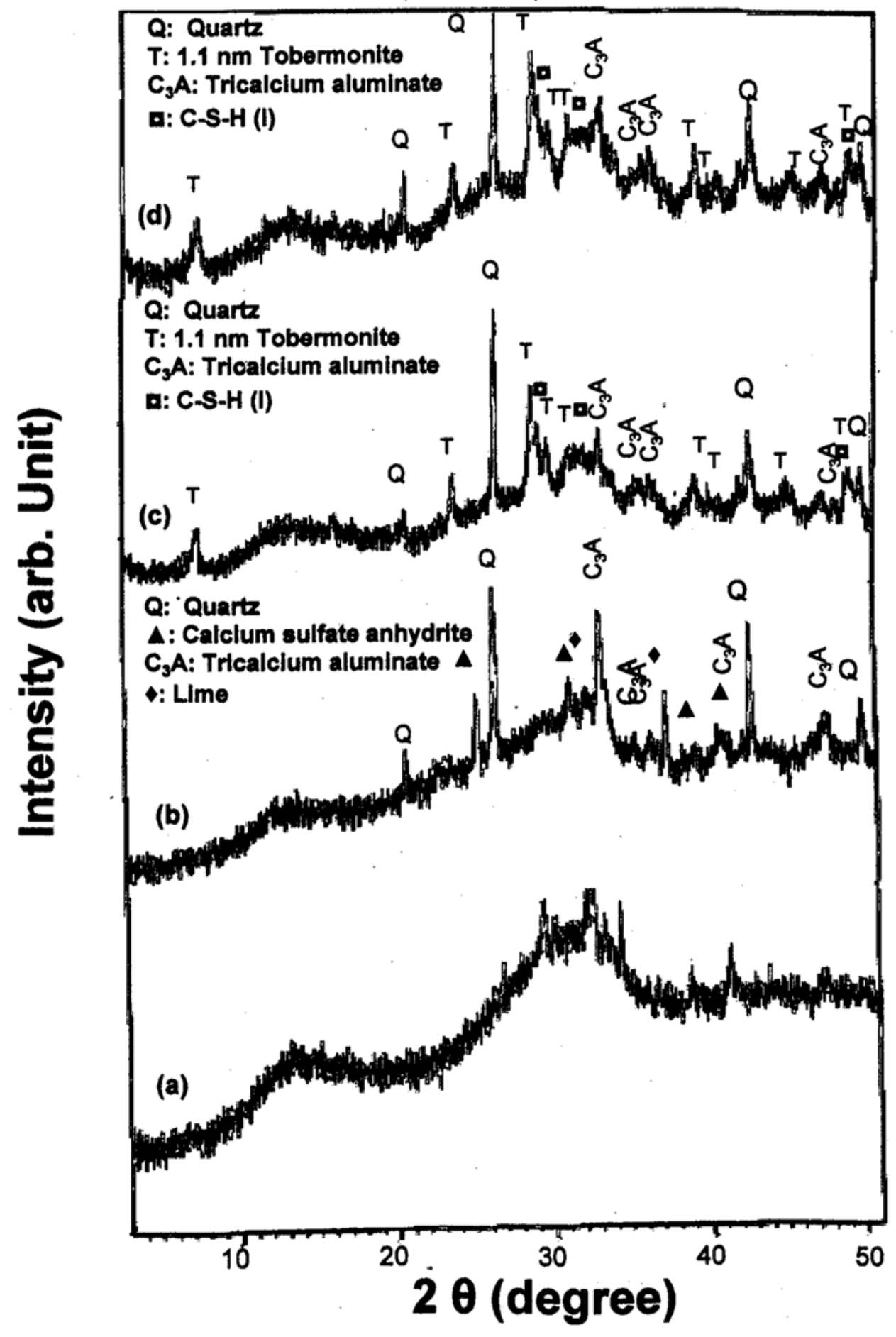

Figure 3. XRD patterns for slag (a), Class $\mathrm{C}$ fly ash (b), $200^{\circ} \mathrm{C}$-autoclaved $20 / 80 \mathrm{C} / \mathrm{S}$ ratio $\mathrm{AACM}$ (c), and autoclaved $20 / 80 \mathrm{~S} / \mathrm{C}$ ratio $\mathrm{AACM}$ after heating at $300^{\circ} \mathrm{C}$ (d). 


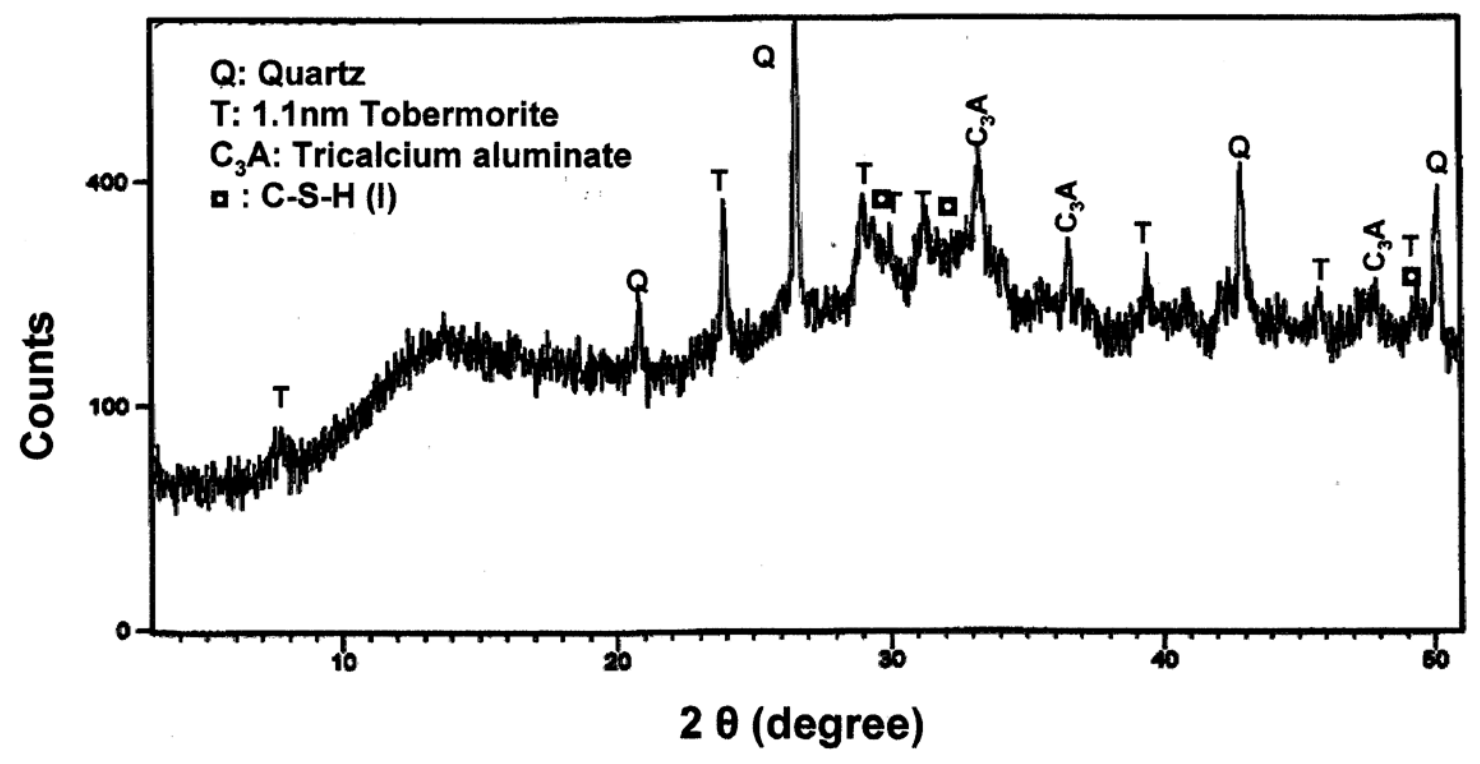

Figure 4. XRD pattern for autoclaved $0 / 100 \mathrm{~S} / \mathrm{C}$ ratio AACM. 


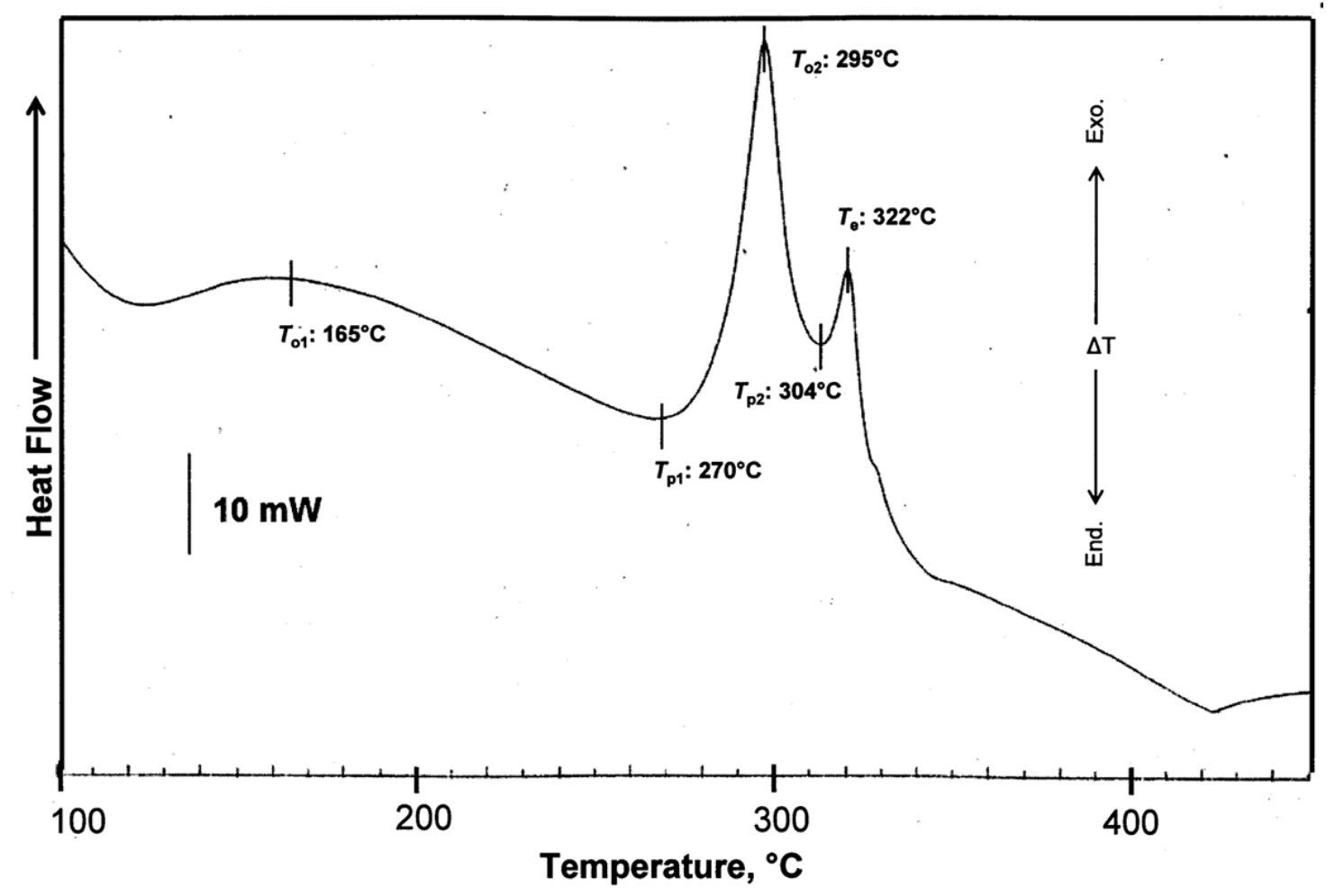

Figure 5. DSC curve of CMC. 


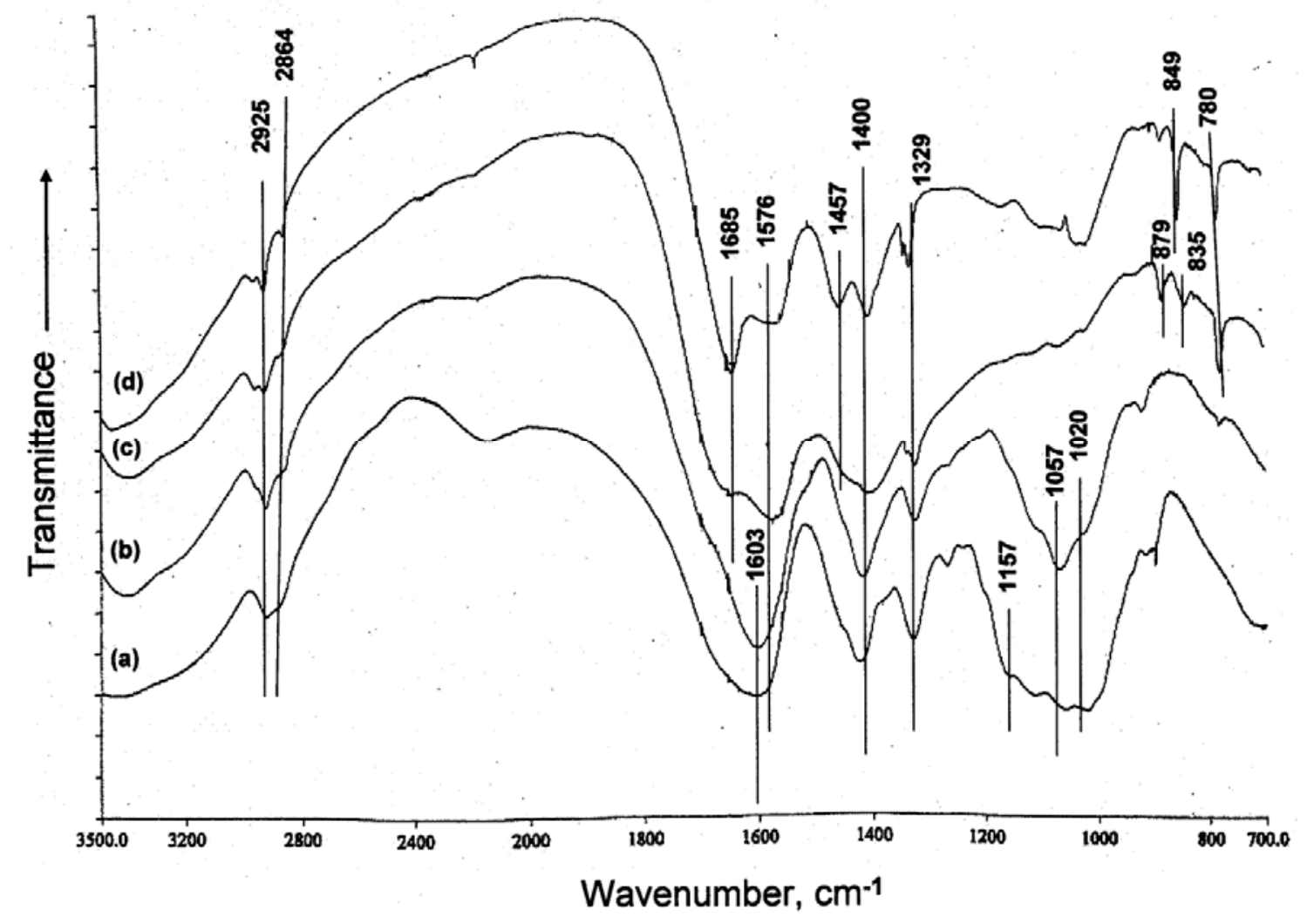

Figure 6. FT-IR spectra for $80^{\circ} \mathrm{C}$-made CMC film (a), and $200^{\circ} \mathrm{C}-(\mathrm{b}), 250^{\circ} \mathrm{C}$-(c), and $300^{\circ} \mathrm{C}$-heated CMCs (d). 


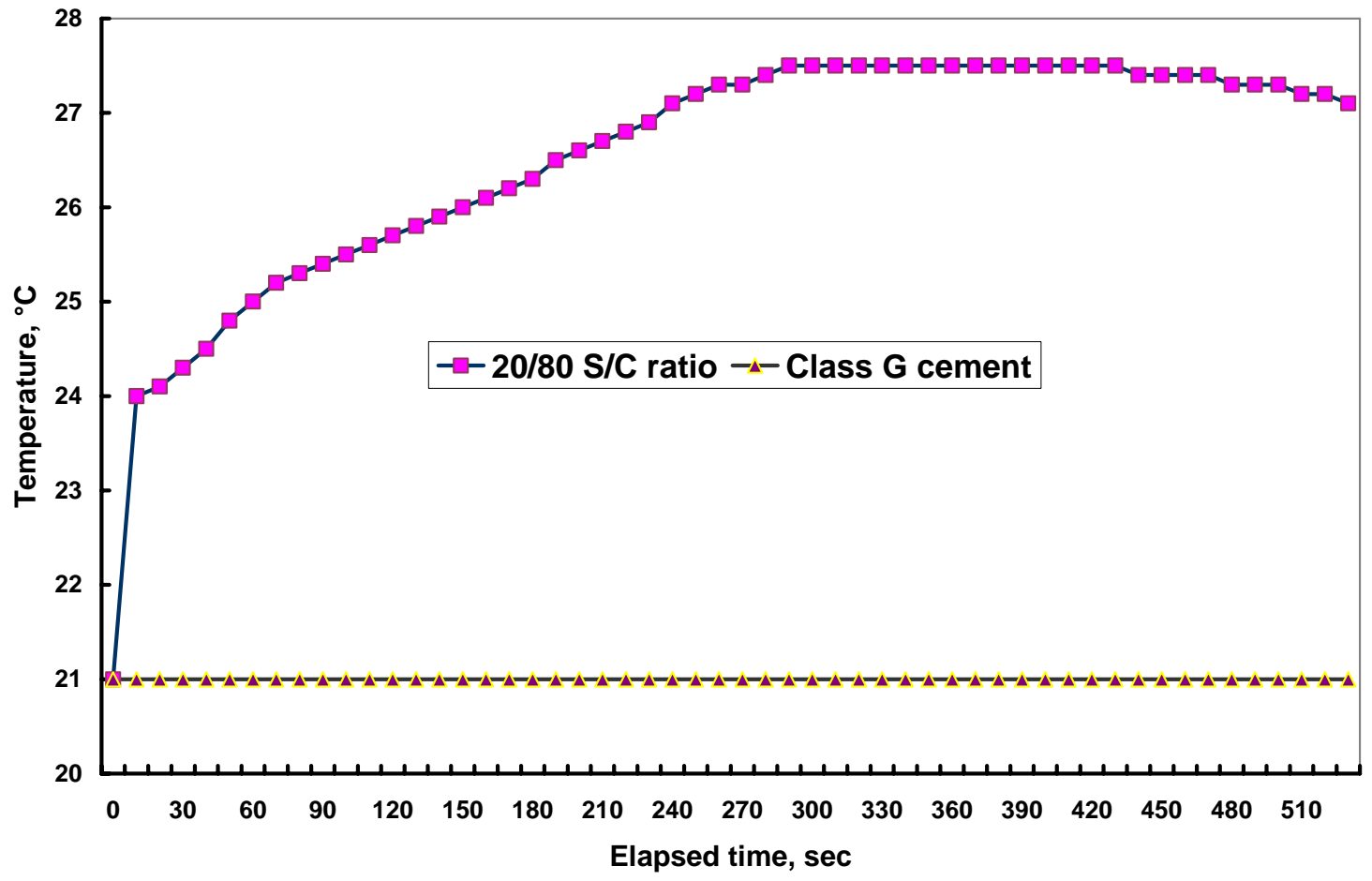

Figure 7. Changes in temperature of $20 / 80 \mathrm{~S} / \mathrm{C}$ and Class $\mathrm{G}$ cement slurries after mixing with water at room temperature as a function of elapsed time. 


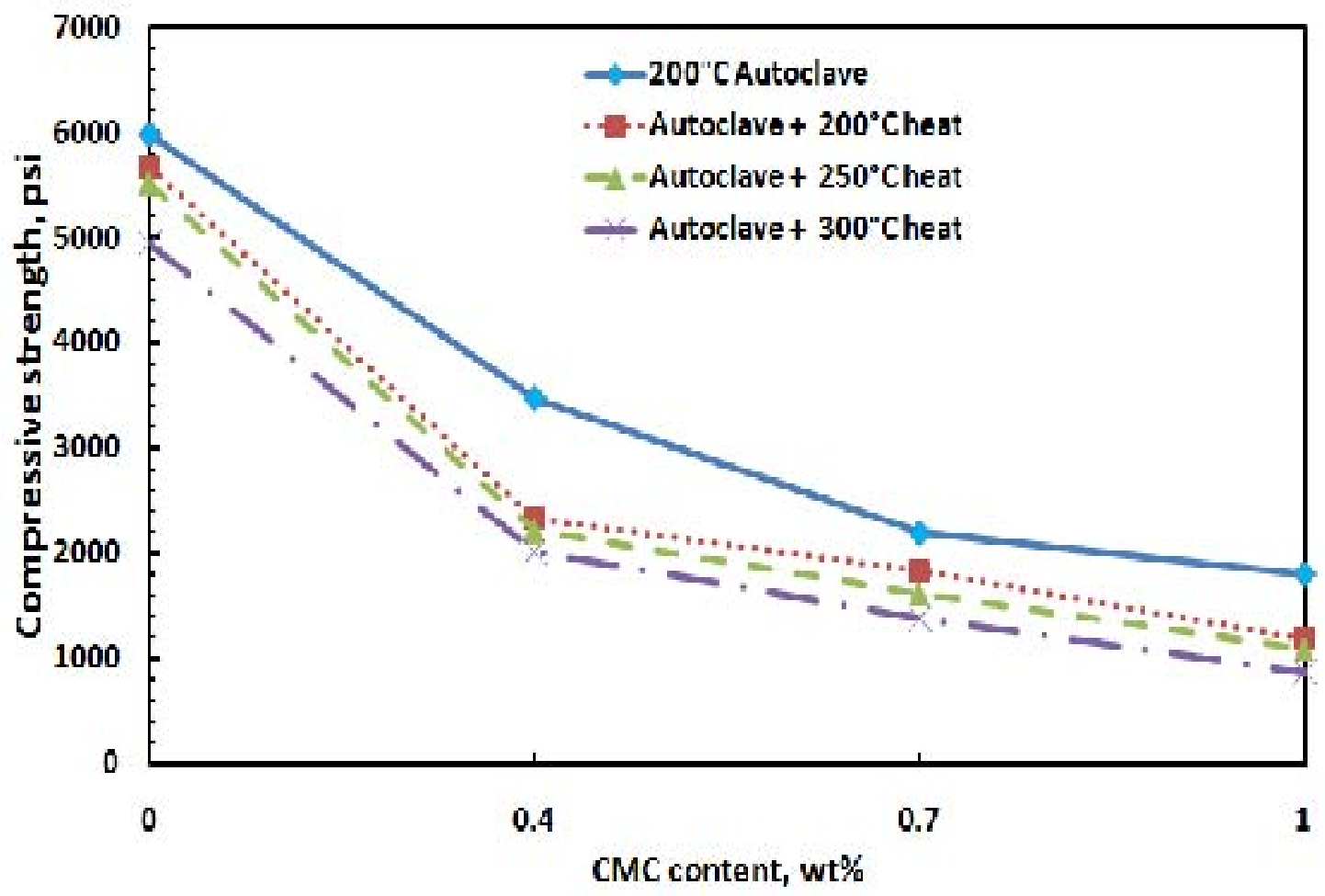

Figure 8. Changes in compressive strength of 20/80 ratio AACM specimens exposed in different thermal environments as a function of $\mathrm{CMC}$ content. 


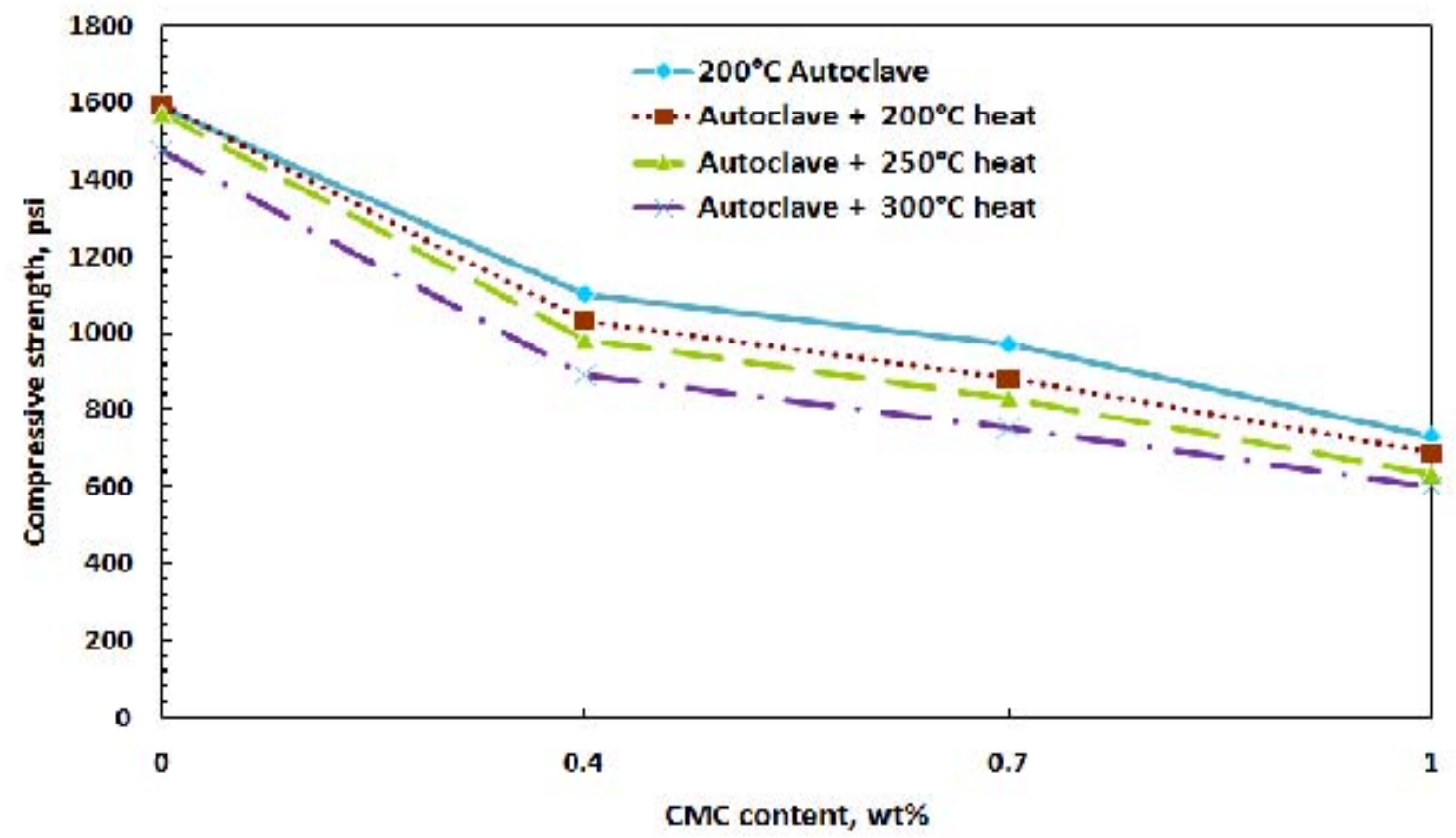

Figure 9. Compressive strength vs.CMC content for Class $\mathrm{G}$ well cements after exposure in the different thermal environments. 


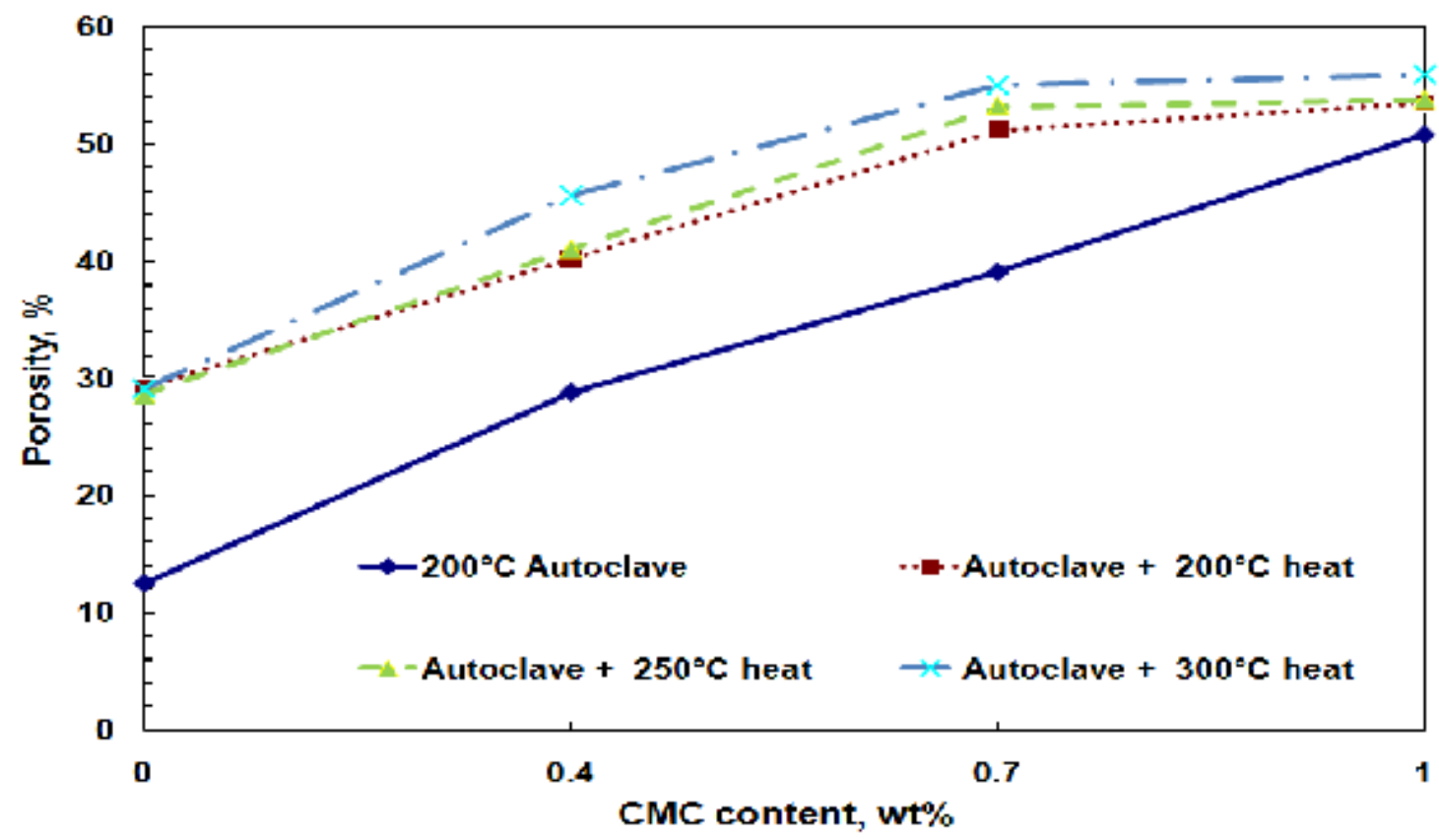

Figure 10. Changes in porosity of 20/80 S/C ratio AACM exposed in the different thermal environments as a function of $\mathrm{CMC}$ content. 


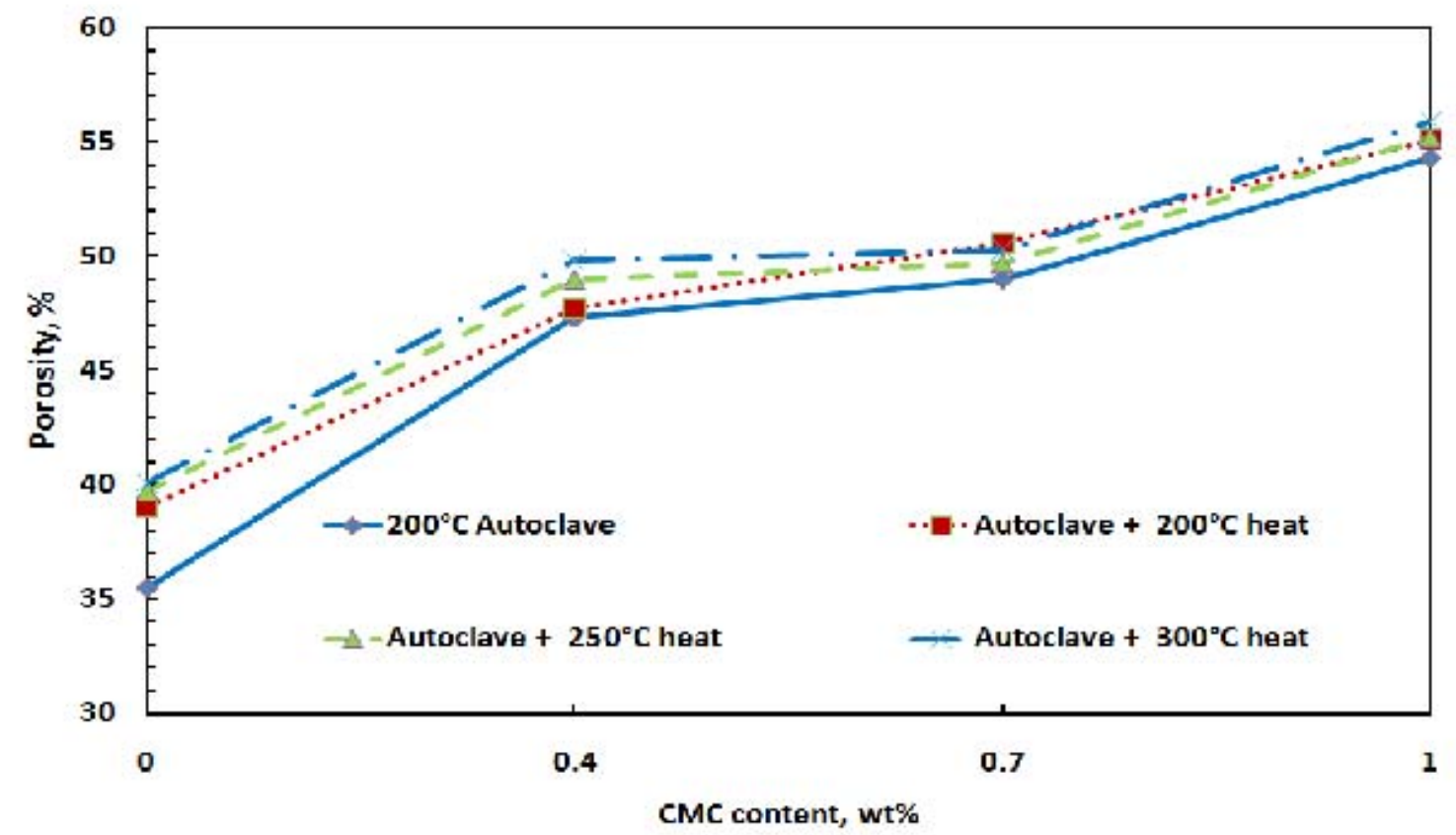

Figure 11. Porosity vs. CMC content for Class $\mathrm{G}$ well cements after exposure in the different thermal environments. 


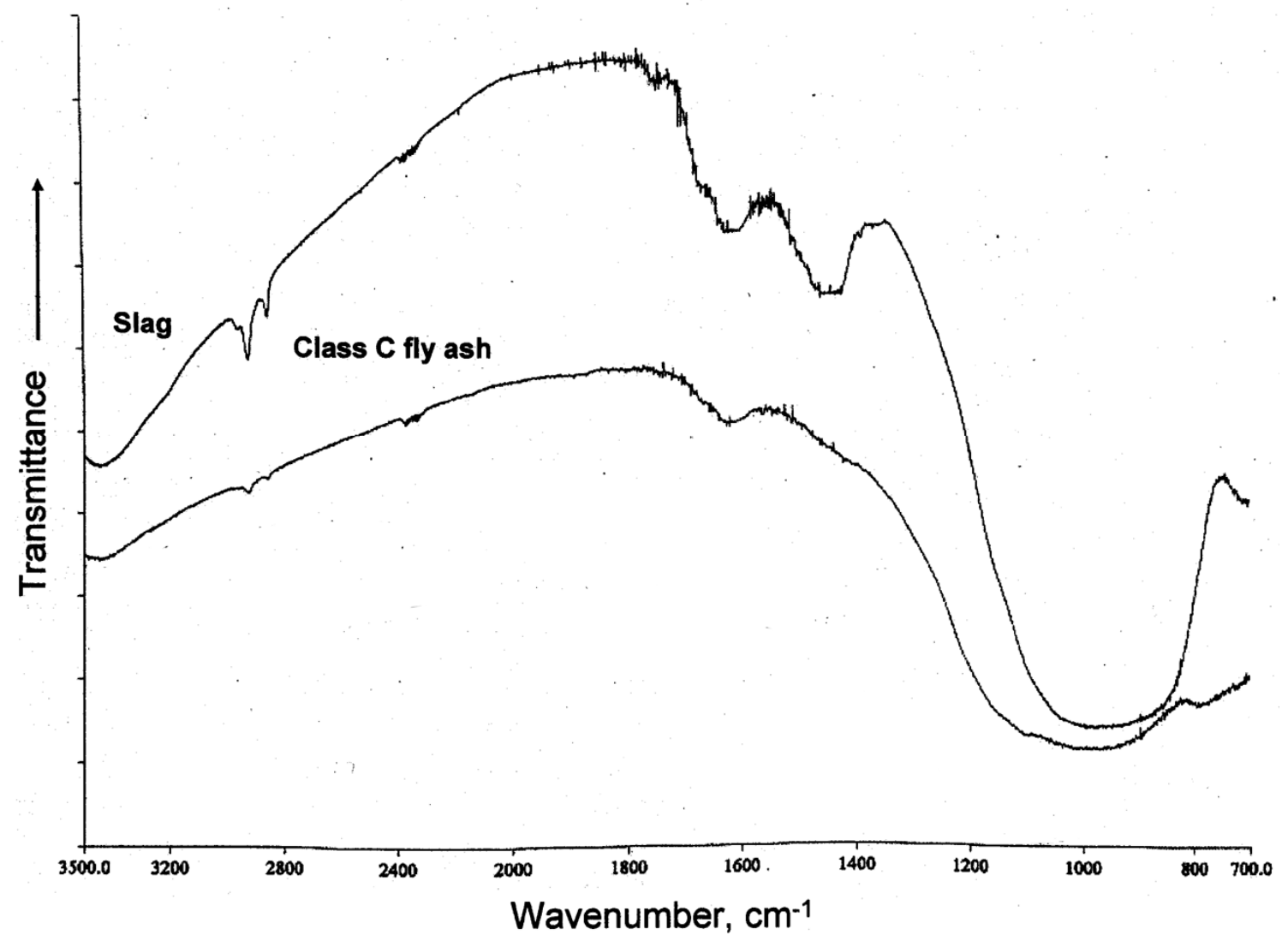

Figure 12. FT-IR spectra for slag and Class C fly ash as references. 


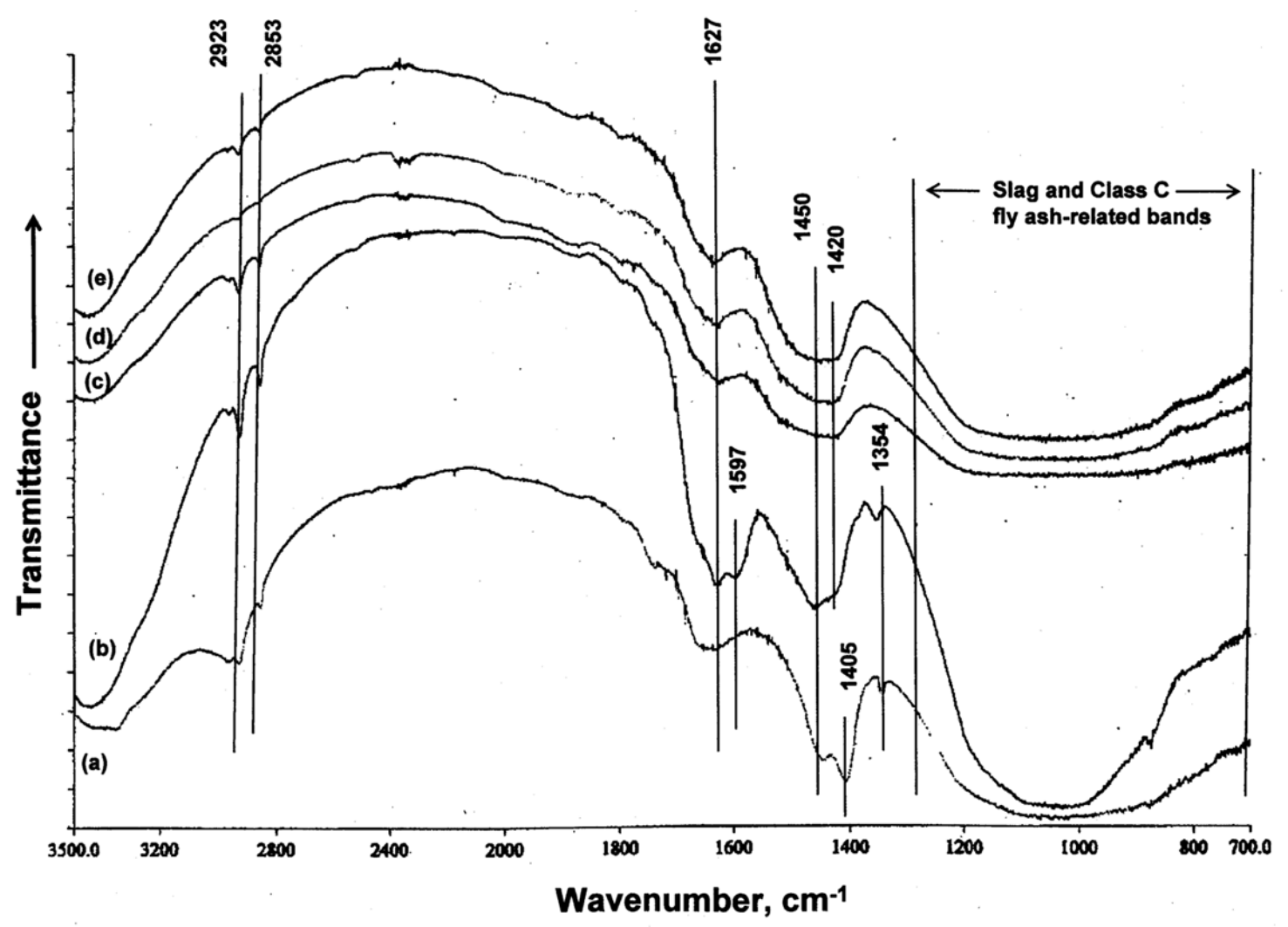

Figure 13. FT-IR spectra for AACM with $1.0 \% \mathrm{CMC} ; 80^{\circ} \mathrm{C}$-heated (a), $200^{\circ} \mathrm{C}$ autoclaved (b), autoclave $+200^{\circ} \mathrm{C}$-heated (c), autoclave $+250^{\circ} \mathrm{C}$-heated (d), and autoclave $+300^{\circ} \mathrm{C}$-heated (e). 

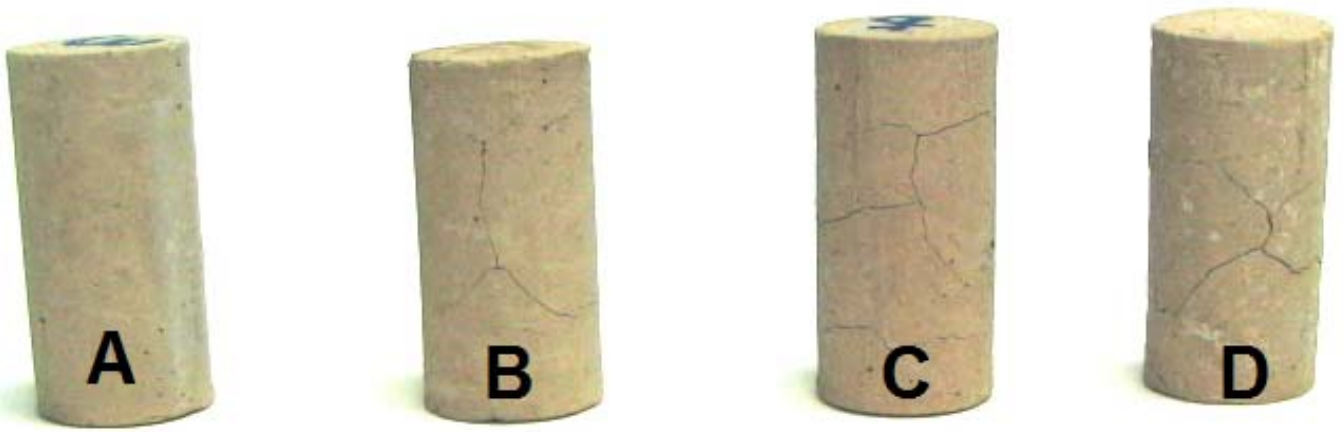

Figure 14. Appearance of $200^{\circ} \mathrm{C}$ - heated $0 \%$ (A), $0.4 \%$ (B), $0.7 \%$ (C), and $1.0 \%$ (D) CMC-modified 20/80 S/C ratio AACMs after immersion in water. 


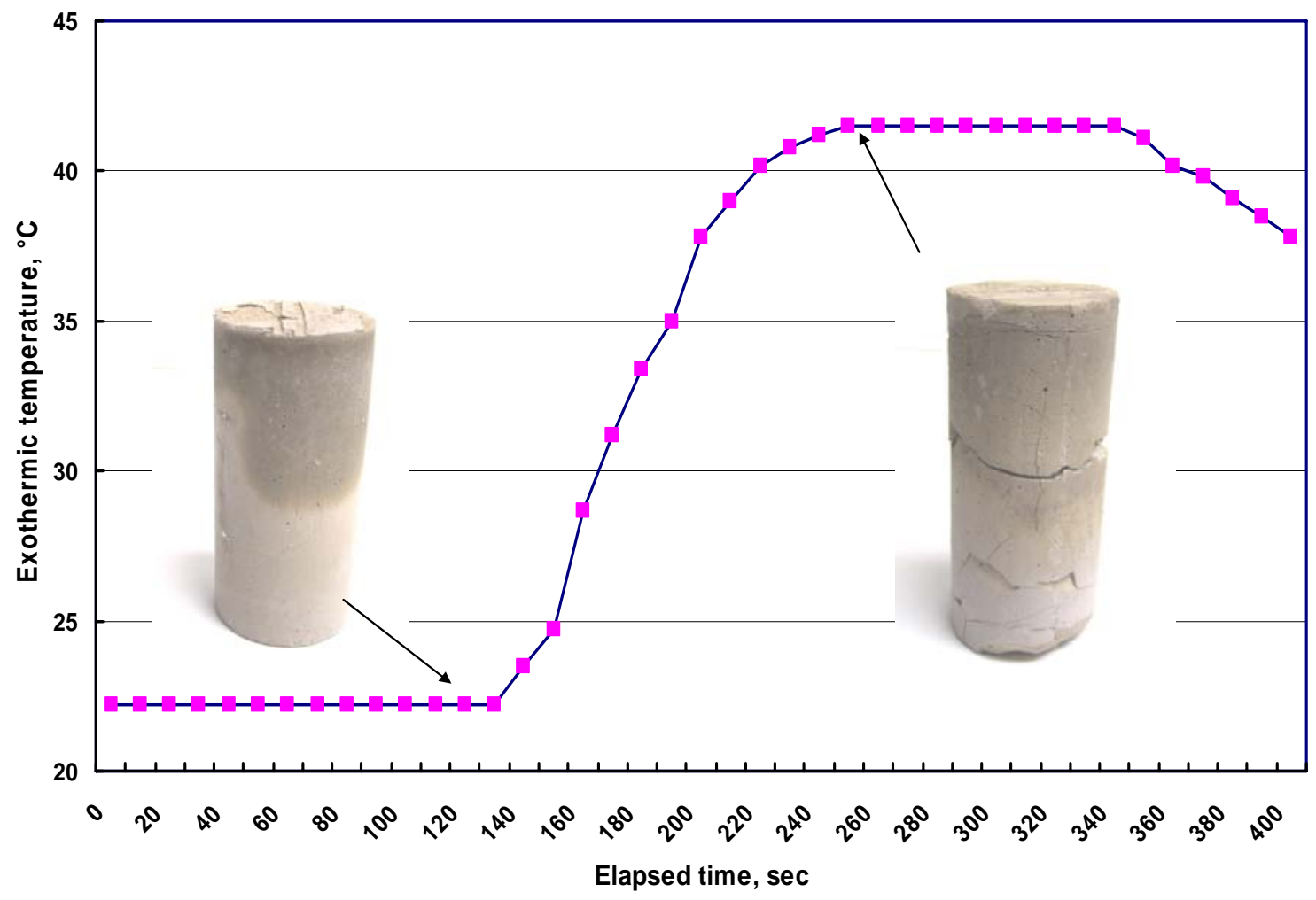

Figure 15. In-situ exothermic temperature vs. elapsed time for $0.7 \%$ CMC-modified AACM after beginning impregnation with water. 


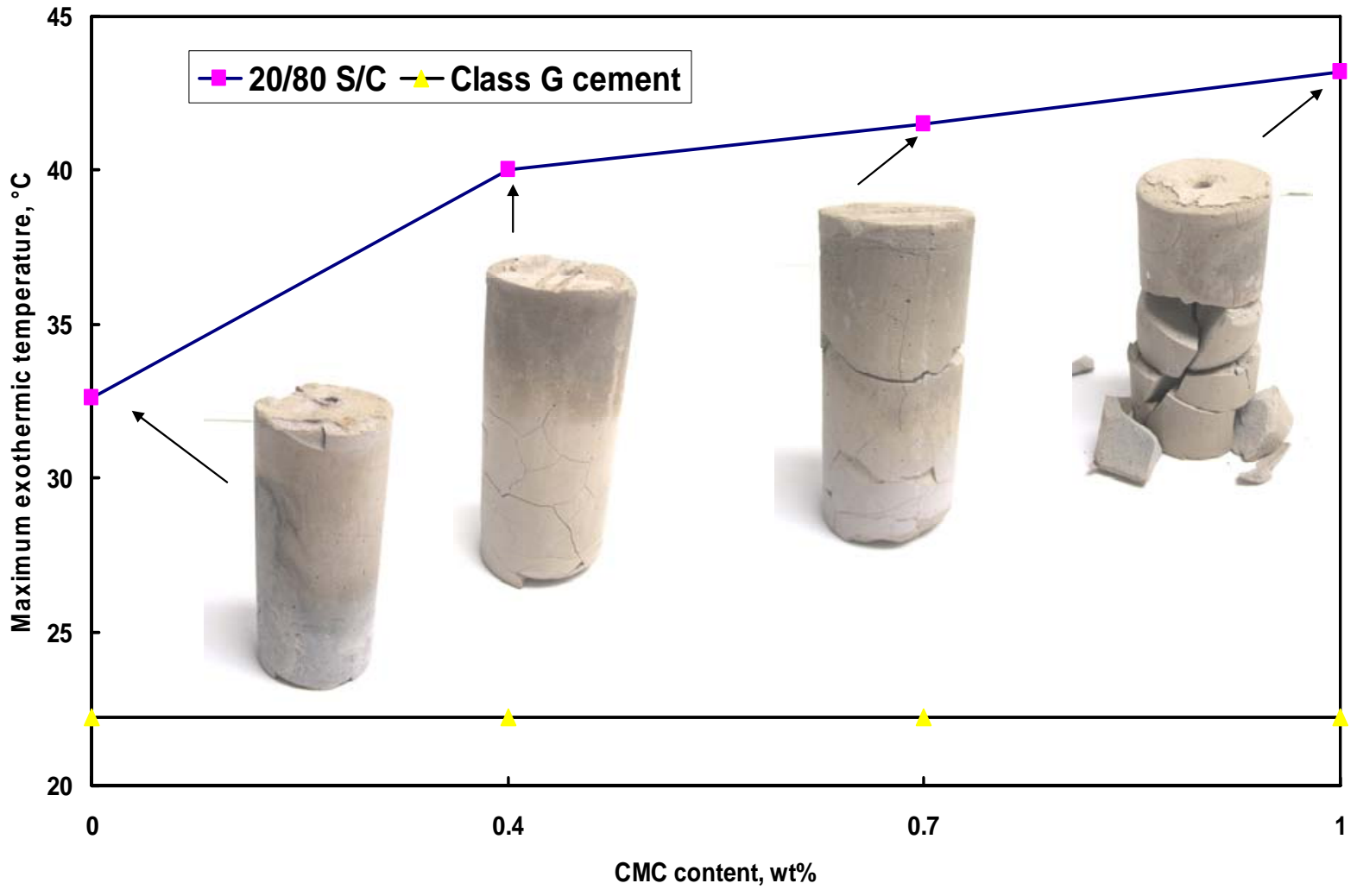

Figure 16. Changes in maximum exothermic temperature generated in AACM and Class $\mathrm{G}$ cement after impregnation with water as a function of $\mathrm{CMC}$ content, and visual comparison of magnitudes of self-degradation. 


\section{Thermal Decompositon of CMC}

$$
\begin{aligned}
& \mathrm{CMC} \longrightarrow \mathrm{CO}_{2}+\mathrm{CO}+\mathrm{CH}_{4}+\mathrm{CH}_{3} \mathrm{COOH}+\mathrm{Na}_{2} \mathrm{CO}_{3} \\
& \text { Acetic acid }
\end{aligned}
$$

Hydrolysis-Wet Carbonation in CMC-modified AAḾC

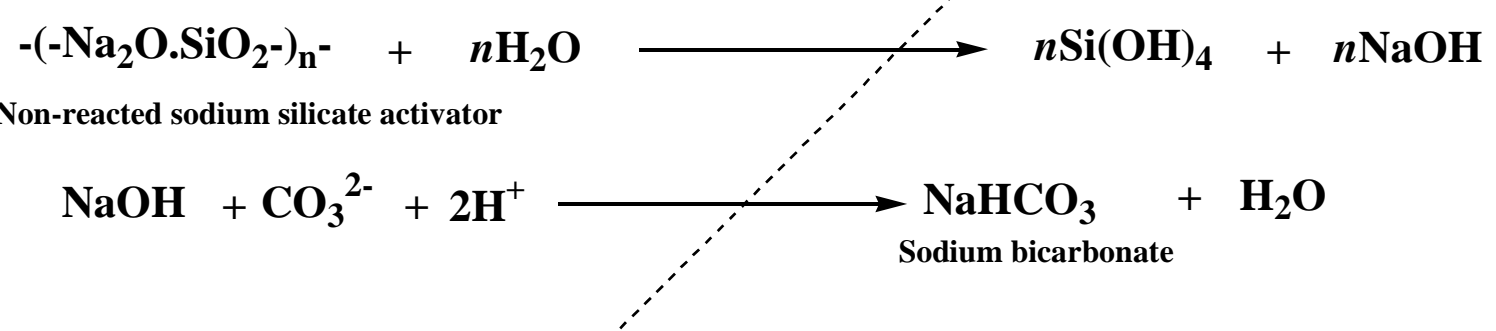

In-situ Exothemic Chemical Réaction

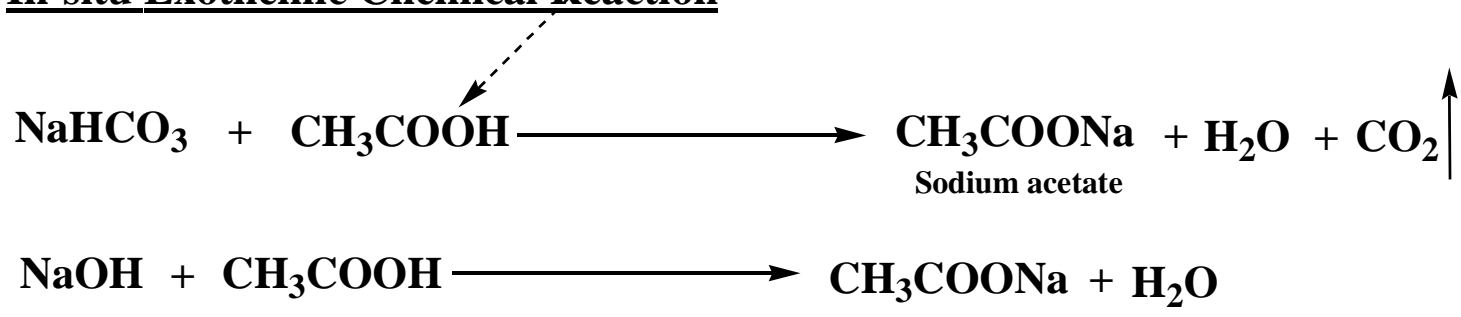

Figure 17. Self-degradation mechanism of heated CMC-modified AACM after contact with water. 